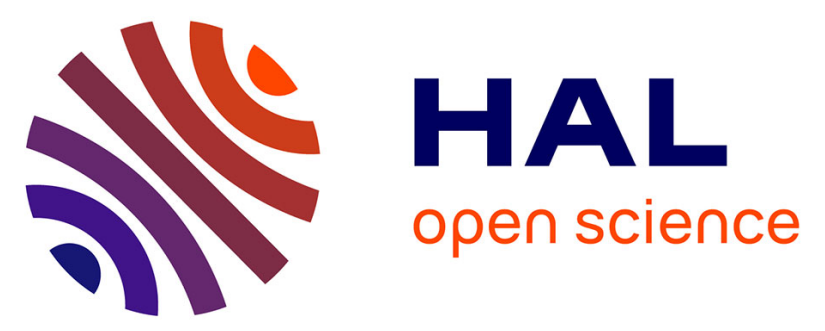

\title{
Tree species mixing affects soil microbial functioning indirectly via root and litter traits and soil parameters in European forests
}

\author{
Lauren M Gillespie, Stephan Hättenschwiler, Alexandru Milcu, Janna \\ Wambsganss, Ammar Shihan, Nathalie Fromin
}

\section{To cite this version:}

Lauren M Gillespie, Stephan Hättenschwiler, Alexandru Milcu, Janna Wambsganss, Ammar Shihan, et al.. Tree species mixing affects soil microbial functioning indirectly via root and litter traits and soil parameters in European forests. Functional Ecology, 2021, 35 (10), pp.2190-2204. 10.1111/13652435.13877 . hal-03377552

\section{HAL Id: hal-03377552 \\ https://hal.science/hal-03377552}

Submitted on 14 Oct 2021

HAL is a multi-disciplinary open access archive for the deposit and dissemination of scientific research documents, whether they are published or not. The documents may come from teaching and research institutions in France or abroad, or from public or private research centers.
L'archive ouverte pluridisciplinaire HAL, est destinée au dépôt et à la diffusion de documents scientifiques de niveau recherche, publiés ou non, émanant des établissements d'enseignement et de recherche français ou étrangers, des laboratoires publics ou privés. 
1 Tree species mixing affects soil microbial functioning indirectly via root and litter traits and

2 soil parameters in European forests

3

4 Authors:

5 Lauren M. Gillespie ${ }^{1}$, Stephan Hättenschwiler ${ }^{1}$, Alexandru Milcu ${ }^{1,2}$, Janna Wambsganss ${ }^{3,4}$, 6 Ammar Shihan ${ }^{1}$, Nathalie Fromin ${ }^{1 \dagger}$

${ }^{1}$ CEFE, Univ Montpellier, CNRS, EPHE, IRD, Montpellier, France

$9 \quad{ }^{2}$ Ecotron Européen de Montpellier, Univ Montpellier, CNRS, Montferrier-sur-Lez, France

${ }^{3}$ Chair of Silviculture, Faculty of Environment and Natural Resources, University of

Freiburg, 79085 Freiburg, Germany

${ }^{4}$ Geobotany, Faculty of Biology, University of Freiburg, 79104, Freiburg, Germany

$\dagger$ present address: CNRS-PROMES, 66120 Odeillo, France

Corresponding author: lgillespie155@gmail.com*

\section{Abstract}

1. Plant community composition influences soil microbial communities through plant trait variations that lead to changes in nutrient and organic carbon inputs into the soil by root exudates and plant litter. Although plant litter and living roots are known to influence microbial functioning independently, their relative effects are rarely measured simultaneously in naturally occurring plant communities. 
2. Here, we sought to evaluate how forest floor litter and absorptive roots affect broad functions of soil microbial communities, and how this may be influenced by tree species mixing. To do so, forest floor litter, absorptive roots, and soil were sampled from monospecific and 3-species mixed stands in four mature, natural forest ecosystems across Europe. The direct effects of tree species mixing, its indirect effects via litter and root traits, and the effects of soil parameters on microbial biomass, catabolic activity and diversity, and denitrification were analyzed.

3. Results did not show direct tree mixture effects on the soil microbial parameters we measured but did suggest indirect influences via tree mixture effects on traits of aboveground litter and absorptive roots and soil parameters. Mixed forests composed of any three tree species modified soil microbial functioning by influencing nutrient availability in forest floor litter and root resource acquisition. Tree mixing also modified soil microbial functioning and catabolic diversity by influencing soil fertility and physicochemical properties.

4. Our findings suggest an indirect but present influence of tree species mixing on the activity of heterotrophic soil microbial communities across four different forest ecosystems ranging from Mediterranean to boreal forests. Our study contributes to a better mechanistic understanding of mixed tree species effects on soil microbial functioning via the modification of forest floor litter properties and traits of absorptive roots represented by the tree community beyond simple species numbers consideration, and potentially via soil properties. 


\section{Introduction}

Soils harbor a highly diverse community of microorganisms that play a crucial role in many ecological processes and impact terrestrial ecosystem functioning and stability (Bardgett \& van der Putten, 2014; Fierer, 2017). Microorganisms control the rate nutrients and carbon are released from dead organic matter and made available to organisms (Crowther et al., 2019) and concurrently release greenhouse gases, notably $\mathrm{CO}_{2}$ and $\mathrm{N}_{2} \mathrm{O}$, into the atmosphere (Robertson \& Groffman, 2007; Singh, Bardgett, Smith, \& Reay, 2010). However, soil microbial activity and its subsequent influence on ecosystem functioning are dependent on many extrinsic factors such as soil properties, climatic conditions, and the plant community (Bardgett \& Caruso, 2020).

Different plant species, and thus different plant community assemblages, can exert significant and contrasting effects on soil microbial communities and associated processes (Eisenhauer et al., 2010; Scheibe et al., 2015; Urbanová, Šnajdr, \& Baldrian, 2015) through differences in litter quality and diversity (Thoms, Gattinger, Jacob, Thomas, \& Gleixner, 2010), rhizodeposition (Steinauer, Chatzinotas, \& Eisenhauer, 2016), root symbionts (Baldrian, 2017), above- and belowground litter production, and microclimatic conditions (e.g. temperature and soil humidity) (Prescott \& Grayston, 2013). Plant diversity effects can be expressed for example, through disproportional effects (either positive or negative) of specific plant species on soil microorganisms, i.e. the sampling effect hypothesis (Aarssen, 2016; Huston, 1997; Tilman, Lehman, \& Thomson, 1997). Species with complementary traits can also lead to nonadditive effects on soil microorganism activities, for example, through the combination of varying litter qualities (Barantal, Schimann, Fromin, \& Hättenschwiler, 2014; Handa et al., 2014) and/or increased root exudate diversity or rate of diffusion (Cesarz et al., 2013; Jones, Hodge, \& Kuzyakov, 2004; Prescott \& Grayston, 2013). Consequently, higher plant exudate and litter diversity and/or quantity could potentially support a more diverse (Cesarz et al., 2013; 
Eisenhauer et al., 2017; Prescott \& Grayston, 2013; Steinauer et al., 2016) and more abundant/active soil microbial community.

Numerous studies have evaluated plant effects on soil microbial processes with a particular focus on effects through litter production and quality (Fanin, Hättenschwiler, \& Fromin, 2014; Hättenschwiler, Tiunov, \& Scheu, 2005; Hatton, Castanha, Torn, \& Bird, 2015; Joly, Fromin, Kiikkilä, \& Hättenschwiler, 2016; Pfeiffer et al., 2013; Thoms et al., 2010), root activity (Cesarz et al., 2013; Eisenhauer et al., 2017; Landi et al., 2006), or microclimatic conditions (Kara, Bolat, Çakiroğlu, \& Öztürk, 2008; Lange et al., 2014; Wu et al., 2012). Indeed, plant litter inputs and live root processes are the two primary pathways by which plants affect soil microbial communities (Baldrian, 2017; Lladó, López-Mondéjar, \& Baldrian, 2017, 2018), yet their relative importance is poorly understood and most studies do not take these factors into account simultaneously.

Plant litter is an important source of organic carbon $(\mathrm{C})$, nitrogen $(\mathrm{N})$, phosphorus $(\mathrm{P})$, and micronutrients for soil microorganisms (Becher, Bernhardt, Fuchs, \& Riedel, 2013; Thomas \& Packham, 2007). Litter can also provide cations that reduce soil acidification, $\mathrm{pH}$ being a key driver in microbial community composition and low $\mathrm{pH}$ being linked to slow litter decomposition (Lladó et al., 2017; Pfeiffer et al., 2013). Since many leaf characteristics, e.g. lignin and polyphenol concentrations, persist after senescence, plant leaf economic strategies (LES, Wright et al., 2004) can dictate species litter effects on decomposition rates and release of resources into the soil (Coq, Souquet, Meudec, Cheynier, \& Hättenschwiler, 2010; Cornwell et al., 2008; Prescott, 2005). For example, conservative leaf traits, associated with higher energy investment in resource conservation and resource immobilization in long-living plant tissues, could negatively affect microbial activity by producing defense compounds (lignin or polyphenols) that can inhibit microorganisms (Freschet, Aerts, \& Cornelissen, 2012; Prescott, 2005). Plants with acquisitive traits, associated with higher investment in growth and resource 
acquisition, tend to have higher quality litter (e.g. lower $\mathrm{C}: \mathrm{N}$ ratio, higher $\mathrm{P}$ content, lower lignin and tannin/polyphenol contents) which is correlated to increased microbial activity and faster litter turnover and influences microbial community composition and biomass (Freschet et al., 2012; Lladó et al., 2017).

Living roots influence soil microbial activity by altering soil physical structure, water flow, and exudation of ions and organic compounds (McCormack et al., 2015; Prescott \& Grayston, 2013). Similar to the leaf economics spectrum, accumulating evidence from root research suggests a universal root economics spectrum (RES) (Bergmann et al., 2020; Roumet et al., 2016). Generally, it seems that higher specific root length (SRL) and nitrogen (N) concentration combined with lower root diameter and tissue density are associated with an acquisitive root resource strategy, while the inverse is associated with a conservative strategy (Kong et al., 2019; Weemstra et al., 2016). In herbaceous species, acquisitive plant species have been found to produce higher amounts of root exudates than conservative species (Guyonnet, Cantarel, Simon, \& Haichar, 2018; Henneron, Cros, Picon-Cochard, Rahimian, \& Fontaine, 2019), which can lead to higher soil microbial biomass and activity (Kaštovská, Edwards, Picek, \& Šantrůčková, 2015). However, the distinction between acquisitive and conservative root strategies and associated traits is presently less clear for woody species (Weemstra et al., 2016), and their effects on the microbial community is not well understood. This is likely due to a combination of spatial and temporal variability in fine-root traits (e.g. season, age, and soil depth), as well as mycorrhizal colonization. The organic matter provided to the soil microbial community in the form of root litter may also stimulate soil microbial activity more efficiently than aboveground litter (Freschet et al., 2013; Hatton et al., 2015; Jackson, Mooney, \& Schulze, 1997) because of tight spatial proximity.

In this study, we evaluate the influences of tree species mixing by comparing single tree species stands to stands with three tree species and their associated litter and root traits on soil 
microbial functioning (microbial respiration, denitrification potential, and catabolic diversity estimated from 15 carbon substrates) in four mature, natural forest ecosystems across Europe (including a total of 13 tree species, 34 different species combinations, and varying soil types). By incorporating a wide range of climate, soil, and forest types we were able to explore general trends of tree characteristics and species mixture influences on microbial functioning beyond site and forest community-specific variations. We hypothesize that, tree species mixtures promote higher soil microbial activity across forest ecosystems irrespective of the biotic and abiotic conditions. We further hypothesize that, while more diverse above-ground litter and below-ground root traits and associated resource inputs to the soil both contribute to these mixture effects, roots have a more dominant role because of their intimate contact with microbial communities in the three-dimensional topsoil space whereas aboveground litter remains largely on the soil surface.

\section{Materials and Methods}

Study sites and sampling protocol: The studied sites are part of a permanent network of mature forest plots established in 2011 and 2012 (detailed site descriptions can be found in Baeten et al., 2013) across Europe: Colline Metallifere (Italy), Râşca (Romania), Białowieża (Poland), and North Karelia (Finland). These forests represent four major European forest types including Mediterranean thermophilous, montane mixed beech, hemiboreal mixed broadleaved-coniferous, and boreal forests (see Table S1 and Figure S1 in Supporting Information). The forests are managed to variable degrees, but species composition is mostly influenced by selective logging, not planting, of naturally established trees. Within each site, $30 \mathrm{~m} \times 30 \mathrm{~m}$ forest plots were selected that had stands composed of either one dominant tree species (mono-specific plot) or three co-dominating tree species (mixed plot); species were defined as co-dominant when it composed $>15 \%$ of the stand. Tree species identity and mixed 
plot tree species combinations varied among sites. Each tree species at each site had two replicate mono-specific plots (with the exception of Picea abies L. and Quercus robur L. plots with one replicate each and Betula pendula Roth with no mono-specific plot in Białowieża, Poland). Mixed plots had a minimum of three replicates per site, but the tree species compositions of these replicates included any three target species present at that site, i.e. mixed plot replicates were not necessarily composed of the same tree species. The final selection of 64 plots included 13 tree species and 34 different species combinations, as well as a wide range of soil types (Table $\mathrm{S} 1)$.

Within each plot, five tree triplets were identified following the approach described by Vivanco \& Austin (2008), a tree triplet being a triangle of three canopy tree individuals with less than $8 \mathrm{~m}$ distance from one another and with no other tree individuals within the triangle. In mono-specific plots, tree triplets were composed of the same tree species, and in mixed plots, each triplet was formed by one individual from each of the three co-dominant trees species of the plot. At the estimated center of each triplet, weighted by tree individual size (individual diameter at breast height), four $15 \times 15 \mathrm{~cm}$ forest floor litter layer samples were collected and dried at $60^{\circ} \mathrm{C}$. All litter material within the square, which was predominantly leaf litter but sometimes included other plant parts such as reproductive structures and small $(<25 \mathrm{~mm}$ diameter) branches, was collected down to the mineral soil, meaning that multiple years of litter accumulation were sampled. We considered the entire decomposing forest floor more representative of how aboveground litter accumulation may affect underlying soil microbial communities than only annual fresh litter fall. Such higher realism came at the cost of distinguishing litter material originating from different tree species within mixture plots, which impeded us from considering functional diversity of litter traits. One soil core $(5.3 \mathrm{~cm}$ diameter $)$ was sampled from the top $10 \mathrm{~cm}$ of soil within each of the four squares where the litter had been removed. This means that the soil cores included the mineral layers starting with the A- 
horizon. The four soil cores sampled within each tree triplet were then combined and sieved through a $2 \mathrm{~mm}$ sieve and air-dried immediately after sampling for soil microbial analyses. One additional soil core was taken in the same location using the same methods and kept intact for root measurements. There were thus five replicate samples for each of the 64 plots for a total of $n=320$ samples (mono-specific plot samples $n=150$, mixed plot samples $n=170$ ) of forest floor, sieved soil, and soil for root measurements.

Soil measurements: The soil bulk density, carbon (C) concentration, carbon:nitrogen $(\mathrm{C}: \mathrm{N})$ ratio, and $\mathrm{pH}$ were measured during the FunDivEUROPE project in 2012 (Baeten et al., 2013; Dawud et al., 2016). For the FunDivEUROPE soil sampling methods see (Dawud et al., 2016). Another set of unground soil subsamples (10 g per sample) were used to determine soil texture. The soil was pre-treated for organic and carbonate removal (ISRIC \& FAO, 2002) if present, the texture was then measured by laser granulometry (Malvern Mastersizer S, Malvern Instruments Limited, Worcestershire, United Kingdom). Soil data are provided in Table S2.

Forest floor litter characterization: Each subplot litter sample (five per plot) was dried at $60^{\circ} \mathrm{C}$, weighed, and the weight was divided by the surface area sampled to be expressed as $\mathrm{kg}$ dry weight litter per square meter of soil surface. After weighing, the entire litter sample was ground to approximately $2 \mathrm{~mm}$ (Retsch cutting mill SM1, Haan, Germany) for homogenization and then a subsample of litter was ground to $1 \mathrm{~mm}$ (Cyclotec 1093 cyclone grinder, Tecator, Höganas, Sweden) for chemical analyses.

The total $\mathrm{C}$ and nitrogen $(\mathrm{N})$ concentrations $(\%)$ of each individual litter sample were measured using the Pregl-Dumas method with a CHN Elemental Analyzser (Flash EA1112 Series, ThermoFinnigan, Milan, Italy) on $3.7 \pm 0.4 \mathrm{mg}$ of litter. The C concentration was then divided by the $\mathrm{N}$ concentration to obtain the litter $\mathrm{C}: \mathrm{N}$ ratio.

For the other litter quality parameters based on methods that take much more time than $\mathrm{C}$ and $\mathrm{N}$ analyses, we used the near infrared spectrum (NIRS) approach for chemical 
characterization of each individual sample. We first determined the NIR spectrum of each of the 320 samples using Fourier-transformed infrared spectroscopy (FTIR) with a NIRFlex N500 spectrometer (BUCHI Corporation, New Castle, DE, United States). The litter samples were scanned in a cuvette $(\mathrm{W} \times \mathrm{D} \times \mathrm{H}: 12.5 \times 12.5 \times 45 \mathrm{~mm})$ with a spectral range from 1000 $\mathrm{nm}-2500 \mathrm{~nm}$ and spectral resolution of $8 \mathrm{~cm}^{-1}$ for 16 scans. Each sample was scanned twice, and the two spectra were averaged. Based on the bulk of obtained spectra, a selection program (NIRWare Management Console, BUCHI Corporation) identified the required number and spread of a subset of samples on which a calibration data base was constructed using the NIRWare NIRCal software (BUCHI Corporation). A total of 87 spectra out of the 320 were selected to accurately represent the sample spectra distribution. The P, lignin, condensed tannins, and total phenolics concentrations were then measured for these 87 samples, which were subsequently used to predict the values for the remaining 233 samples based on their individual near infrared spectra (NIRWare NIRCal software). The program tested multiple methods as well as multiple transformations to obtain the best regression coefficient, using twothirds of the spectra for calibration and one-third for validation. The calibration methods, transformations, and calibration and validation results are detailed in Table S3; the $r^{2}$ values for all litter quality parameters were all larger than 0.76 .

The $\mathrm{P}$ concentration was measured colorimetrically using the molybdate blue method (Grimshaw, Allen, \& Parkinson, 1989). First, $84.0 \pm 4.0 \mathrm{mg}$ of litter was mineralized by adding $8 \mathrm{ml}$ of $\mathrm{HNO}_{3}\left(2.24 \mathrm{~mol} \mathrm{~L}^{-1}\right)$ and, over $10 \mathrm{~min}$, heated to $120^{\circ} \mathrm{C}$, then over 20 minutes, heated to $175^{\circ} \mathrm{C}$ and kept at this temperature for $10 \mathrm{~min}$ in an ETHOS One microwave (Milestone, Via Fatebenefratelli 1/5-24010 Sorisol, Italy). Once the sample cooled, $100 \mu 1$ was deposited in each well of a 96-DeepWell Microplate (Fisher Scientific E39199) and $100 \mu 1 \mathrm{NaOH}(2 \mathrm{~mol} \mathrm{~L}-$ $\left.{ }^{1}\right), 50 \mu 1$ sodium molybdate $\left(7 \mathrm{~g} \mathrm{~L}^{-1}\right)$, and $50 \mu 1$ ascorbic acid $\left(10 \mathrm{~g} \mathrm{~L}^{-1}\right)$ was added in that order. 
The plate was incubated at $40^{\circ} \mathrm{C}$ for 30 minutes then the optic density was read (wavelength $720 \mathrm{~nm}$ ) with a Victor 1420 Multilabel Counter (PerkinElmer, Massachusetts, USA).

Cellulose, hemicellulose, and lignin fractions were measured with the FIBERSAC ${ }^{\circledR}$ method 12 (Fibersac 24, Ankom, Macedon, NJ, USA; Ankom Technology, 2017) adapted from Van Soest (1963). Following this protocol, plant tissue constituents were extracted and measured gravimetrically by sequentially exposing $510.0 \pm 10.0 \mathrm{mg}$ dry weight of the litter sample to neutral detergent (NDS), acid detergent (ADS), and $\mathrm{H}_{2} \mathrm{SO}_{4}(72 \%)$.

The concentration of condensed tannins was measured by spectrophotometry with the butanol-HCl method (Porter, Hrstich, \& Chan, 1985; Waterman \& Mole, 1994) as described in detail by Coq et al. (2010). Total phenolic concentration was measured colorimetrically, using the method described by Ribéreau-Graydon (1972) and using the Hach TanniVer ${ }^{\mathrm{TM}}$ reagent (Hach Company, Loveland, CO, USA), according to the detailed description in Coq et al. (2010). Extractions were diluted when necessary. Forest floor litter data are provided in Table $\mathrm{S} 2$.

Absorptive root traits: Roots were sorted from the soil cores and all fine roots $(<2 \mathrm{~mm}$ in diameter) were subsequently classified as absorptive (the first three root orders) or transport roots $\left(4^{\text {th }}\right.$ and $5^{\text {th }}$ order roots) according to the functional classification approach by McCormack et al. (2015). On average, absorptive roots of the target species made up $53.5 \pm 2.4 \%$ of all fine roots (absorptive and transport roots combined). For further details on the root sorting and measurement methods see (Wambsganss, Beyer, Freschet, Scherer-Lorenzen, \& Bauhus, 2021). This order-based approach was used, as opposed to the still commonly applied traditional diameter classification, because studies have shown that the first three most distal root orders (i.e. the absorptive roots according to McCormack et al. (2015)) significantly differ in their functions from higher order roots. The absorptive roots are responsible for most of the resource uptake (absorption), and thus exudation, and are therefore more relevant in affecting 
microorganisms than higher order roots (Guo et al., 2008; McCormack et al., 2015). The morphological absorptive root traits reflect root growth, resource capture strategies, and associated functioning (Bardgett, Mommer, \& De Vries, 2014; McCormack \& Iversen, 2019; Weemstra et al., 2016). Absorptive root trait data are provided in Table S2.

Soil microbial parameters: Soil microbial analyses were done on soils that were air-dried immediately after sampling, because it was not possible to work on fresh soils for logistical reasons (geographical spread of the sampling sites, time required for sampling all the plots, sample shipping constraints). Air-drying has been found to not significantly impact microbial community composition and structure (Wang et al., 2021), but even if shifts in microbial parameters occur, the relative differences in $\mathrm{C}$ and $\mathrm{N}$ transformations between samples are generally preserved (Makarov, Mulyukova, Malysheva, \& Menyailo, 2013).

Classical substrate induced respiration (SIR) method was used to measure the potentially active microbial biomass (Beare, Neely, Coleman, \& Hargrove, 1990). This method allows to determine glucose-induced respiration activity as the amount of $\mathrm{CO}_{2}$ produced under optimal conditions over a short duration ( 4 hours), to measure the active enzyme pool respiration before new enzymes can be synthesized or new microbial growth (Fanin, Hättenschwiler, Barantal, Schimann, \& Fromin, 2011 for methods). The active microbial biomass ( $\mu \mathrm{g} \mathrm{C}_{\mathrm{mic}} \mathrm{g}^{-1}$ dry soil) was then estimated using the calculation proposed by Anderson and Domsch (1978): SIR rate $\left(\mu \mathrm{l} \mathrm{C}-\mathrm{CO}_{2} \mathrm{~g}^{-1}\right.$ dry soil h $\left.\mathrm{h}^{-1}\right) * 40.04+0.37$.

The MicroResp ${ }^{\mathrm{TM}}$ method described by Shihan et al. (2017) was used to determine the catabolic diversity of soil microorganisms, based on the ability of the soil microbial community to respire on a range of various $\mathrm{C}$ substrates $\left(\mu \mathrm{g} \mathrm{C}-\mathrm{CO}_{2} \mathrm{~g}^{-1}\right.$ dry soil $\left.\mathrm{h}^{-1}\right)$. We used the same 15 different C sources as described in detail by Shihan et al. (2017). Three technical replicates were run per substrate with approximately $0.39 \mathrm{~g}$ of soil dry weight per replicate. The substrate addition equated to $1.5 \mathrm{mg}$ of $\mathrm{C}$ per g dry weight of soil. The SIR rates of all 15 substrates were 
summed to obtain a global catabolic respiration value (Sum15). The Shannon metabolic diversity index for each subplot was calculated using the formula: $H^{\prime}=-\sum_{i=1}^{15} p i \mathrm{x} \ln (p i)$ where $p i$ is the standardized respiration rate for the substrate ' $i$ ', i.e. the respiration rate of substrate ' $i$ ' divided by the Sum 15 value. For the respiration rate of each of the $15 \mathrm{C}$ sources, a substrate was considered 'used' by the microbial community when the respiration rate was $15 \%$ higher relative to the respiration without the addition of a $\mathrm{C}$ substrate (i.e. just water), all respiration rates below this threshold were considered not-used and were replaced by zeros for the ANOSIM and GLMM analyses (see below).

Potential microbial denitrification enzyme activity (DEA, $\mu \mathrm{g} \mathrm{N}-\mathrm{N}_{2} \mathrm{O} \mathrm{g}^{-1}$ dry soil $\mathrm{h}^{-1}$ ) was measured using the acetylene inhibition method described by Smith \& Tiedje (1979) as described by Pinay et al. (2007). This is a measure of the potential denitrification activity since it is conducted under optimal conditions and the enzyme concentration is the only activitylimiting factor.

Statistical Analysis: The R software (R Development Core Team, 2008) (version 3.5.3) was used for all figures and statistical analyses, figures were made using the 'pirateplot' function from the YaRrr! Package (version 0.1.5, Phillips, 2018), the function 'fviz_pca_biplot' from the factoextra package (version 1.0.6, Kassambara \& Mundt, 2019), and the function 'radarchart' in the fmsb package (version 0.7.0, Nakazawa, 2019). The QGIS software (version 3.12.3) was used to create the sampling locations map (Figure S1) with a basemap from $\underline{\text { www.naturalearthdata.com. }}$

To take into account the site-specificity of the soil parameters in subsequent analyses, the soil variables were incorporated into a principal component analyses (PCA) using the function 'prcomp' from the factoextra package (version 1.0.6, Kassambara \& Mundt, 2019) (Fig. 1a) and the PC scores of the first two axes were extracted. The extracted PCA scores were then 
included in the general linear models and structural equation models as explanatory variables. This was also done for the chosen forest floor litter characteristics and the absorptive root traits. Generalized mixed-effects linear models were run, using the lme4 package (version 1.1-21; Bates et al., 2019), on each response variable ( $\mathrm{C}_{\text {mic }}$, Sum15, $H^{\prime}$, and DEA) testing the effect of the explanatory variables (Litter PC1, Litter PC2, Root PC1, Root PC2, Sol PC1, Soil PC2, and tree mixture). Response variables were transformed $(\log 2)$ when necessary, and extreme values ( $> \pm 3$ times the interquartile range) were removed (the number of removed values never exceeded $10 \%$ of the total number of values). The site, which takes into account all associated site-specific differences such as climatic variables, and plot were included as random variables. The model structure was as follows: response variable $\sim$ Litter PC1 + Litter PC2 + Root PC1 + Root PC2 + Soil PC1 + Soil PC2 + Tree species number + (1|Site/Plot). In order to identify the most parsimonious models and the most consistent predictors we used a model averaging approach via the 'dredge' and 'model.avg' functions in the MuMIn package (Bartoń, 2019) which uses the lowest Akaike Information Criteria (AIC) to rank all possible models with all possible combinations of the explanatory variables in the full model. A 95\% confidence set was used to select a subset of the models to be averaged, i.e. average of the estimates, calculated using the zero method (Burnham \& Anderson, 2002), with the standard error, importance value, $\mathrm{z}$-value, and p-value. The importance value is calculated by summing the model weights of the models where the variable appears.

Before testing the respiration rates of the substrates considered to be 'used' (see definition above) at a univariate level, we first tested them at the multivariate level. An analysis of similarities (ANOSIM) was performed on the 'used' substrate respiration rates using the function 'anosim' in the vegan package (version 2.5-6; Oksanen et al., 2019) to explore the influence of the explanatory variables listed above. Data were averaged at the plot level since 'anosim' can only accept one random variable, i.e. pooling the five within-plot measurements 
to a single mean value with site as the only random variable. Since the ANOSIM results showed a marginally significant tree species mixing effect on the multi-substrate use (Table 2), we ran univariate GLMMs, using the same model structure and method as before, on each individual substrate. The data were analyzed at the sub-plot level for the GLMMs since this analysis can accept multiple random variables.

Structural Equation Modelling (SEM; Grace et al., 2015) was used to test the support for a network of hypothesized causal relationships between tree species mixing, forest floor litter characteristics, absorptive root traits, and soil parameters on soil microbial functioning. The piecewiseSEM package (version 2.1.0; Lefcheck et al., 2019) was used to build SEMs for each microbial response variable $\left(\mathrm{C}_{\text {mic }}\right.$, Sum15, $H^{\prime}$, DEA) excluding the individual $15 \mathrm{C}$ substrate values, see Figure S2 for the model structure. Tree species mixture was included as an exogenous variable with influence on the microbial functional response variable directly and indirectly via Soil PC1, Litter PC1, and Root PC1. The response variables were transformed $(\log 2)$ when necessary before running the SEM. Because there were insufficient data points to include all axes simultaneously, we constructed a second identically structured SEM with the second axes (i.e. Litter PC2, Root PC2, and Soil PC2). Additional SEMs were also created to explore whether litter and root parameters indirectly influenced the microbial variables via the soil parameters. Model goodness of fit was analyzed using the test of directed separation by combing all p-values across the basis set in the Fisher's $C$ test statistic and comparing it to a $\chi^{2}$ distribution with $2 \mathrm{k}$ degrees of freedom. The model has a good fit when $\mathrm{p}$ of the $\chi^{2}$ test $>0.05$. We tested all PC1 and PC2 combinations possible, and mixing PC1 and PC2 variables within a SEM did not change the results or, in the case of Soil PC1 or PC2 effects on opposite Litter or Root PC axes (e.g. Soil PC1 effect on Litter PC2), were not significant. We therefore present the SEM results as a SEM constructed with PC1 variables and a second SEM with the PC2 variables. 


\section{Results}

Soil parameters, forest floor litter traits, and traits of absorptive root varied widely among

the four studied forests across Europe (Fig. 1). The first axis of the soil parameter PCA (Soil PC1) accounted for $52.5 \%$ of the variance and was mostly determined by soil physicochemical properties (Fig. 1a). High bulk density was associated with negative PC scores, and high pH, C, and clay concentrations were associated with positive scores. The second axis (Soil PC2) explained $24.9 \%$ of variance, with negative PC scores correlated with low C:N ratio. The first axis of the forest floor litter trait PCA (Litter PC1) accounted for 50.2\% of the variance, with negative PC scores associated to high concentrations of phenolic compounds and positive scores to high concentrations of lignin (Fig. 1b). The second axis (Litter PC2) accounted for $23.7 \%$ of the variance, with negative PC scores associated with high $\mathrm{C}: \mathrm{N}$ ratio and low $\mathrm{P}$ and positive $\mathrm{PC}$ scores to low $\mathrm{C}: \mathrm{N}$ ratio and high $\mathrm{P}$. The first axis of the PCA on traits of absorptive roots (Root PC1) accounted for $42.2 \%$ of the variance, with negative scores associated with high SRL, RLD, and surface area and positive scores associated with high diameter and RTD (Fig. 1c). The second axis (Root PC2) captured 26.9\% of the variance and was mainly related to the root surface area (negative scores) and ECM colonization intensity (positive scores; Fig. 1c).

Overall, mixed forest plots had higher Litter PC2 scores (higher P concentration and lower C:N ratio), lower Root PC1 (high SRL, RLD, and surface area), and higher Root PC2 scores (higher ECM colonization intensity and lower root surface area) compared to mono-specific plots. Between sites, Litter PC1, Litter PC2, Root PC1, and Root PC2 were reasonably comparable, with slight deviation for the Finnish Litter PC1, and had generally consistent patterns between mono-specific and mixed plots (Figure S3). Slightly more deviation was found 
for soil PC scores, particularly for Soil PC1 where the sites in Italy and Romania were distinct from the sites in Finland and Poland.

Across all 320 collected soil samples, we measured an average $C$ microbial biomass $\left(C_{\text {mic }}\right)$ of $166.0 \pm 92.7 \mu \mathrm{g} \mathrm{C}_{\text {mic }} \mathrm{g}^{-1}$ dry soil, with a very large 20 -fold range between 28.8 and $568.5 \mu \mathrm{g}$ $\mathrm{C}_{\text {mic }} \mathrm{g}^{-1}$ dry soil (Fig. 2a). The average denitrification enzyme activity (DEA) was $0.01 \pm 0.014$ $\mu \mathrm{g} \mathrm{N}-\mathrm{N}_{2} \mathrm{O} \mathrm{g}{ }^{-1}$ dry soil $\mathrm{h}^{-1}$, ranging between 0.00 and $0.06 \mu \mathrm{g} \mathrm{N}-\mathrm{N}_{2} \mathrm{O} \mathrm{g}^{-1}$ dry soil h ${ }^{-1}$ (Fig. 2b). The average sum of the microbial catabolic respiration rate induced by 15 different $\mathrm{C}$-sources (Sum15) was $62.7 \pm 34.5 \mu \mathrm{g} \mathrm{C}-\mathrm{CO}_{2} \mathrm{~g}^{-1}$ dry soil $\mathrm{h}^{-1}$ and ranged between 26.1 and $204.3 \mu \mathrm{g} \mathrm{C}$ $\mathrm{CO}_{2} \mathrm{~g}^{-1}$ dry soil $\mathrm{h}^{-1}$ (Fig. 2c). We measured an average Shannon metabolic diversity index $\left(H^{\prime}\right)$ of $2.69 \pm 0.014$ (unitless), with a range between 2.64 and 2.71 (Fig. $2 \mathrm{~d}$ ). Across the 15 substrates included, the average 'used' $\mathrm{C}$ substrate respiration rate was $2.51 \pm 3.51 \mathrm{C}^{-\mathrm{CO}_{2} \mathrm{~g}^{-1} \text { dry soil h}}{ }^{-1}$ and was lowest for vanillic acid $\left(0.68 \pm 2.0 \mu \mathrm{g} \mathrm{C}-\mathrm{CO}_{2} \mathrm{~g}^{-1}\right.$ dry soil $\left.\mathrm{h}^{-1}\right)$ and highest for oxalic acid $\left(5.47 \pm 5.22 \mu \mathrm{g} \mathrm{C}-\mathrm{CO}_{2} \mathrm{~g}^{-1}\right.$ dry soil $\left.\mathrm{h}^{-1}\right)$ (Fig. 3). The microbial variables (i.e. biomass, DEA, sum15, $H^{\prime}$, and substrate use) were generally comparable between sites and had similar patterns between mono-specific and mixed plots, except for higher DEA rates in mixed compared to monospecific stands in Finland and Romania (Supplementary Figs 4).

The GLMMs showed no direct tree species mixing effects, i.e. no difference between soils from mono-specific and mixed tree species stands, on any of the measured microbial activity parameters (Table 1, Fig. 2). The ANOSIM results showed a marginally significant difference between mono-specific and mixed stands for the respiration rates calculated from the 'used' C substrates only (Table 2, Fig. 3). However, none of the univariate GLMMs run for each substrate individually showed a tree species mixing effect (Table S5).

Variations in forest floor litter and absorptive roots traits showed some effects on soil microbial variables but appeared response variable-dependent (Table 1). There was no significant Root PC1 effect, but both $\mathrm{C}_{\mathrm{mic}}$ and Sum15 rates showed a coherent negative 
correlation with Root PC2, i.e. higher $\mathrm{C}_{\mathrm{mic}}$ and Sum15 associated with higher root surface area and lower ECM colonization intensity (the two variables that best represent Root PC2; Fig. 1c). DEA was the only microbial parameter we assessed that was significantly affected by litter traits (Table 1). DEA was positively correlated with Litter PC2 scores, indicating that DEA was higher when the litter layer had high litter P concentrations and low C:N ratios (Fig. 1b). The multivariate analysis on the 'used' substrates (with respiration rates above the threshold of $15 \%$ higher than that of pure water addition; see Materials \& Methods) showed that the 'used' substrate profiles were not affected by litter parameters nor Root PC1 but, as for microbial biomass and Sum15, were related to Root PC2 (Table 2). The univariate GLMM analyses run on the 'used' substrate respiration rates for each individual substrate showed no correlation between litter or root PC1 or PC2 scores and substrate use (Table S5).

Soil parameters had the most consistent effects on soil microbial response variables. Microbial biomass, Sum15, $H^{\prime}$, and DEA all varied significantly along the first soil PCA axis (Table 1) associated with variation in $\mathrm{pH}$, clay and organic matter content $(\mathrm{C})$, and bulk density (Fig. 1a). While microbial biomass, Sum15, and DEA increased with Soil PC1 scores corresponding to soils with finer texture and higher $\mathrm{pH}$, we observed the opposite for $H^{\prime}$ ' (Table 1). None of the tested microbial variables varied significantly along the soil PC2 axis (Table 1). The use of the different C substrates was affected by both Soil PC1 and Soil PC2 scores (Table 2). At univariate substrate level, higher Soil PC1 scores were correlated with higher respiration rates of one carbohydrate (D-glucose), three amino acids (L-asparagine, L-serine, and Lglutamine), and two carboxylic acids (oxalic acid and malic acid), while lower Soil PC2 scores were related to higher oxalic acid use only (Table S5).

With structural equation modeling (SEM), we found an indirect tree species mixing effect on the measured microbial response variables (Fig. 4). There were strong and consistent tree species mixture effects on soil parameters (Soil PC1 and PC2), forest floor litter nutrient 
characteristics (Litter PC2) and traits of absorptive roots (Root PC1 and PC2) (Fig. 4). Mixed tree species stands were related to lower Soil PC1, Soil PC2, and Root PC1 scores, and to higher Litter PC2 and Root PC2 scores, regardless of which of the four microbial response variables was fitted (see also Figure S3). These tree mixture effects on soil physicochemical parameters, forest floor litter characteristics, and absorptive root traits had some cascading effects on microbial activity. Tree species mixing indirectly, negatively influenced microbial biomass, DEA, and Sum15 through its negative affect on Soil PC1 (i.e. lower soil pH, clay and C content and higher soil density). Microbial $H^{\prime}$ however, was positively, indirectly influenced by tree species mixing through its effects on Soil PC1, but negatively, indirectly influenced by its effects on Soil PC2, i.e. lower soil fertility in mixed stands leading to lower $H^{\prime}$. Tree species mixing indirectly, positively influenced DEA through its positive effect on Litter PC2, that is to say mixed tree species stands had higher nutrient availability (lower $\mathrm{C}: \mathrm{N}$ and higher $\mathrm{P}$ ) leading to higher potential denitrification activity. In addition, tree species mixing indirectly, negatively influenced microbial biomass and Sum15 though its positive effect on Root PC2 (Fig. 4a,c), meaning mixed tree species stands had lower root surface area and higher ECM colonization leading to lower microbial biomass and catabolic activity. Soil PC1 also had a consistent positive correlation with Litter PC1 (lower soil density and higher pH, clay and C contents leading to higher litter lignin and lower litter tannin/phenolics concentrations), while Soil PC2 had a negative effect on Litter PC2 in the DEA model (lower soil C:N and C content and higher bulk density leading to higher litter $\mathrm{P}$ concentration and lower $\mathrm{C}: \mathrm{N})$. These may have also been pathways by which tree species mixing influenced $H^{\prime}$ and DEA.

\section{Discussion}

With the measurements of soil microbial functioning in our study, we did not detect direct tree species mixture effects over four mature natural forests across Europe, encompassing a 
wide range of climate, soil, and forest types. However, despite the absence of direct tree species mixture effects, we found that tree mixing indirectly affected soil microbial parameters through changes in tree functional traits, which partly confirms our first hypothesis, and potentially through changes in soil parameters.

These results from natural forest stands of varying site conditions differ from those obtained in synthetic single site experiments. For example, the long-term Jena experiment, manipulating herbaceous species diversity, showed a positive correlation between species richness (Eisenhauer et al., 2010; Lange et al., 2015) or root exudate diversity (Steinauer et al., 2016) and soil microbial biomass and activity. Similarly, the findings from a young tree plantation experiment support enhanced soil microbial biomass and activity in soil from communities with higher tree species richness (Khlifa, Paquette, Messier, Reich, \& Munson, 2017). Compared to these single site experiments, our four study sites from different climate zones and with mature trees and distinct soil properties introduced more variation in a range of factors, making the detection of species mixing effects more difficult. However, in a recent meta-analysis covering a wide range of species (herbaceous and woody), habitat types (natural, artificial/planted, in container, forest, grassland, and cropland), successional stages, and climate zones, Chen et al. (2019) reported an overall higher soil microbial biomass and activity with increasing plant species richness. The studies they considered in their meta-analysis covered a much wider diversity gradient (from one up to 60 species combinations) and increasing plant species richness was the main driver of the observed generally positive biodiversity effects on soil microbial parameters. It seems therefore likely that the comparatively small difference from one to three tree species in the forests we studied did not allow the detection of a more general species richness effect potentially expressed at wider species richness gradients. Species identity effects may further outweigh mixture effects on soil microbial community composition and/or functioning (L. Chen et al., 2019; Dijkstra, West, Hobbie, \& Reich, 2009; Scheibe et al., 
2015), particularly in a design with a low diversity gradient such as ours. However, since we did not have the same species at the four sites, we could not introduce species identity as a covariable in our statistical models, which is an unavoidable trade-off when working on natural forests and may have contributed to obscuring direct diversity effects.

Despite the wide range of tree species and forest ecosystems covered by our study, tree mixtures had some general influence on the traits of forest floor litter and absorptive roots and on soil parameters, which appear to consequently affect soil microbial activity indirectly. Mixed stands generally displayed higher Litter PC2 scores (Fig. 1b, Figure S3), related to higher litter $\mathrm{P}$ concentrations and lower $\mathrm{C}: \mathrm{N}$ ratios, indicating higher nutrient availability and potentially faster litter decomposition (Prescott, 2005). Higher decomposition rates lead to faster cycling and lower immobilization of nutrients, which could lead to a more balanced soil nutrient stoichiometry beneficial to soil microorganisms (Cleveland \& Liptzin, 2007; Thomas \& Packham, 2007). Tree mixtures also increase the probability of including complementary traits or substrates with non-additive effects on the microbial functioning (Joly et al., 2016). Higher forest floor litter $\mathrm{P}$ concentrations and lower $\mathrm{C}: \mathrm{N}$ ratios associated with mixed stands are potentially an indirect stimulus of the higher DEA rates, as seen in the hierarchical PC2 SEM (Fig. 4b). Higher nitrogen mineralization rates have been correlated with mixed tree species stands (Forrester, 2017) and could lead to higher soil $\mathrm{N}$ availability for DEA. In correlation, higher litter turnover could increase $\mathrm{C}$ and nitrate availability, which typically limits denitrification (Robertson \& Groffman, 2007). This lends support to the hypothesis that tree mixtures indirectly influence DEA through influences on forest floor litter quality and decomposability. These findings are in line with those of Thoms et al. (2010), who showed that aboveground tree species diversity (up to three species) stimulated soil microbial diversity mostly through indirect interactions with specific plant traits rather than by the tree species diversity itself. 
Mixture effects on leaf defense-related compounds (Litter PC1) or forest floor nutrient availability (Litter PC2) did not translate into an effect on microbial biomass $\left(\mathrm{C}_{\mathrm{mic}}\right)$, metabolic respiration (Sum15), metabolic diversity $\left(H^{\prime}\right)$, or the range of $\mathrm{C}$ substrates used by the soil microbial community. This could mean that soil microbial biomass and $\mathrm{C}$-use are insensitive to the observed differences in forest floor chemistry between single and mixed species forests. The forest floor chemistry variability among the forests composed of different tree species was likely too large for such differences to be expressed, asindicated by the considerable overlap in forest floor characteristics between single species forests and tree mixtures (Fig. 1b). Litter trait diversity is what usually affects microbial biomass and activity in the litter layer, potentially leading to altered decomposition (Handa et al., 2014; Kou et al., 2020) and higher microbial abundance and diversity (Santonja et al., 2017). However, the impact on soil microbial communities is less understood. Controlled laboratory (Fanin et al., 2014; Pfeiffer et al., 2013) and field (Thoms et al., 2010) studies showed that soil microbial communities responded differently to various leaf litters decomposing at the soil surface and that tree litter leachate mixtures had non-additive, short-term effects on soil microbial activity (Joly et al., 2016). Our results from a field setting suggest that such litter effects may not be easily distinguished from numerous other sources of variation playing out at broader spatial scales, such as changing tree species identity.

Contrary to our second hypothesis, traits of absorptive roots did not show more pronounced mixture effects on the measured soil microbial responses than the forest floor litter traits. Higher Root PC2 scores in mixed stands (Fig. 4, Figure S3), meaning lower root surface area and higher ECM colonization intensity (Fig. 1c), lead to lower microbial biomass and respiration potential (Sum15). This may indicate that mixed stands are higher on the fungal collaboration gradient (i.e. higher reliance on mycorrhizal partners for soil space exploration/exploitation and therefore resource acquisition; Bergmann et al., 2020). However, this effect is subtle and on 
average microbial biomass and Sum15 rates were not significantly different between stand types (Fig. 2a,c). Furthermore, metabolic diversity $\left(H^{\prime}\right)$ was not affected by Root PC2 scores. Root PC2 effects on microbial respiration but not on catabolic diversity may indicate microbial communities with different activity levels but equally diverse metabolic capabilities. This would entail changes in substrate use, which was seen for overall 'used' substrate respiration rate (ANOSIM results) but not at the individual substrate level (GLMM results).

Despite the strong, negative tree mixture effect on Root PC1, appearing to represent a gradient in economic strategy (Fig. 1c), Root PC1 in turn only affected Sum15 but no other microbial variable (Fig. 4). The distinction between acquisitive and conservative root strategies is presently less clear for woody species than for herbaceous species, and mycorrhizal interactions were a proposed reason offsetting the presence of a RES (Bergmann et al., 2020; Kong et al., 2019; Ma et al., 2018; McCormack \& Iversen, 2019). This is likely applicable to the findings here considering the robust Root PC2 effect found, the Root PC2 axis being strongly associated to mycorrhizal colonization intensity. Indeed, the Root PC2 effect may lay along the "do it yourself" (i.e. roots that efficiently explore the soil space by themselves with a typically high SRL) vs. "outsourcing" (i.e. roots that rely more on mycorrhizal partners for soil resource acquisition correlated with a large root diameter) gradient correlated to microbial root associations (Bergmann et al., 2020).

We acknowledge that the forest floor and tree root traits measured here are not exhaustive, and missing traits could have influenced findings. For example, the composition and quantity of root exudates could elucidate possible root effects on soil microbial functioning associated with tree species mixing (Steinauer et al., 2016). A more detailed analysis of carbon quality from forest floor and root exudates or decomposing roots may allow a better understanding of how tree mixtures affect soil microbial activity (Sun et al., 2018).

Soil parameters had the strongest and most consistent effects on microbial responses, especially those defining the variance of Soil PC1 with increasing scores associated to higher 
$\mathrm{pH}$, organic matter and clay concentrations and lower bulk density. Indeed, these soil parameters are principal factors determining soil microbial community composition and functioning (Fierer \& Jackson, 2006; Paul, 2007; Thomas \& Packham, 2007). In our study, higher Soil PC1 scores were correlated with higher potential respiration rates (Sum15 and DEA) and microbial biomass, while inversely correlated with catabolic diversity $\left(H^{\prime}\right)$. Clay content strongly affects microbial community structure due to its often higher nutrient stocks and desiccation protection for bacteria (Frey, 2015; Scheibe et al., 2015; Thoms et al., 2010). In addition, the use of the $15 \mathrm{C}$-substrates was overall influenced by these soil parameters but effects on individual substrates were not universal. SEM results also showed a possible indirect influence of tree species mixing on soil microbial functioning via its correlation with soil parameters, physicochemical parameters (Soil PC1) in particular. However, potential patterns seen in the SEMs were not always supported by GLMM results or in contradiction to one another. For example, the indirect, negative mixed tree species effect on DEA via it's negative correlation with Soil PC1 is contradictory to the indirect, positive tree species mixing effect on DEA via Litter PC2. This complex dynamic is possibly the reason for the non-significant, direct tree species mixing effect on soil microbial functioning; a combination of positive and negative mixing effects may have cancelled each other. Indeed, the studied system is intricate, with multi-directional, hierarchal pathways by which trees species mixing can affect microbial functioning. This complexity is not even taking into consideration the reciprocal influences between the studied parameters. Notably, although tree species diversity influences soil properties (Reich et al., 2005), soil properties also determine plant species composition and diversity (Lafleur, Paré, Munson, \& Bergeron, 2010; van Breemen, Finzi, \& Canham, 1997). The predominant direction of this reciprocal influence is not clear in the forests studied here, because although they are mostly naturally established, i.e. soil properties influenced forest 
establishment, they are also mature stands, meaning the trees have had time to significantly alter soil parameters.

The soil C:N ratio (related to Soil PC2), a potential indicator of soil fertility or nutrient limitation (Cleveland \& Liptzin, 2007), did not affect microbial biomass, activity (Sum15 or DEA), or metabolic diversity $\left(H^{\prime}\right)$. These variables are measured under non-limiting conditions (i.e. substrate additions) and would therefore obscure any $\mathrm{C}$ - and to a lesser degree $\mathrm{N}$-limitation effects. The soil C:N ratio had a strong correlation with overall 'used' $\mathrm{C}$ substrate respiration dissimilarity (i.e. ANOSIM results). However, this correlation appears to be primarily driven by the negative relationship between soil $\mathrm{C}: \mathrm{N}$ ratio and oxalic acid use, which may indicate that soils less limited in $\mathrm{N}$ permit a larger microbial response to the addition of oxalic acid.

\section{Conclusion}

The main interest of our study is that it covers a wide range of forests, tree species, and environmental conditions seeking to understand whether there are any general patterns of tree species mixing on broad functions of soil microbial communities. A strong result of our study was that, compared to single tree species forests, mixed forests composed of any three tree species modify soil microbial biomass and functioning indirectly through traits of the forest floor litter and of absorptive roots and potentially through soil parameters across forests as different as Mediterranean and boreal forests. This result helps for a better mechanistic understanding of mixed tree species effects on soil microbial functioning beyond simple species number considerations. The studied system is however, complex and disentangling the effects of individual parameters is difficult at the large spatial scale of our study. The consequences of changes in tree species composition in response to species loss, climate change, or management decisions for soil microbial functioning may thus be largely determined by the modification of 
593

594

595

596

597

598

599

600

601

602

603

604

605

606

607

608

609

610

611

612

613

614

615

616

617

soil properties, forest floor litter properties, and the traits of absorptive roots represented by the newly established tree communities.

\section{Author contributions}

L.G., N.F., S.H., and A.M. developed the study design, planned and assisted in field sampling, and participated in article redaction. L.G. performed the forest floor litter analyses, J.W. performed the root measurements and assisted in article redaction, and A.S. performed the soil microbial activity measurements.

\section{Competing Interests statement}

The author declares no competing interests.

\section{Data availability}

The datasets generated during and/or analyzed during the current study are available from the corresponding author on reasonable request. This data is stored as excel files on a data portal associated with the FunDivEUROPE and SoilForEUROPE projects and available after a 1- year embargo (data url: https://data.botanik.uni-halle.de/fundiveurope/datasets/523).

\section{Acknowledgements}

This research was part of the SoilForEUROPE project funded through the 2015-2016 BiodivERsA COFUND call for research proposals, with the national funders Agence Nationale de la Recherche (ANR, France), Belgian Science Policy Office (BELSPO, Belgium), Deutsche Forschungsgemeinschaft (DFG, Germany), Research Foundation Flanders (FWO, Belgium), and The Swedish Research Council (FORMAS, Sweden). We thank the site managers Leena Finér with the Finnish Forest Research Institute (Metla), Bogdan Jaroszewicz with the 
618 University of Warsaw, Olivier Bouriaud with the Forest Research and Management Institute 619 (ICAS), and Filippo Bussotti and Federico Selvi with University of Florence and associates, as 620 well as Jakub Zaremba, Ewa Chećko, Iulian Dănilă, Timo Domisch and the SoilForEUROPE 621 consortium for their assistance with the field sampling. We also thank Bart Muys and Karen 622 Vancampenhout at KU Leuven University for the soil texture data. Litter characteristics and 623 microbial functioning measurements were conducted at the experimental platform PACE at 624 CEFE Montpellier, France. Root samples and trait measurements were processed at the Chair 625 of Silviculture, University of Freiburg. 


\section{References:}

Aarssen, L. W. (2016). High Productivity in Grassland Ecosystems : Effected by Species Diversity or Productive Species? Published by: Wiley on behalf of Nordic Society Oikos Stable URL : http://www.jstor.org/stable/3546531 Linked references are available. Oikos, 80(1), 183-184.

Anderson, J. P. E., \& Domsch, K. H. (1978). A physiological method for the quantitative measurement of microbial biomass in soils. Soil Biology and Biochemistry, 10(3), 215221. https://doi.org/10.1016/0038-0717(78)90099-8

Ankom Technology. (2017). Acid Detergent Fiber in Feeds -Filter Bag Technique (for A2000 and A2000I); Method 12.

Baeten, L., Verheyen, K., Wirth, C., Bruelheide, H., Bussotti, F., Finér, L., ... SchererLorenzen, M. (2013). A novel comparative research platform designed to determine the functional significance of tree species diversity in European forests. Perspectives in Plant Ecology, Evolution and Systematics, 15(5), 281-291. https://doi.org/10.1016/J.PPEES.2013.07.002

Baldrian, P. (2017). Forest microbiome: Diversity, complexity and dynamics. FEMS Microbiology Reviews, 41(2), 109-130. https://doi.org/10.1093/femsre/fuw040

Barantal, S., Schimann, H., Fromin, N., \& Hättenschwiler, S. (2014). C, N and P fertilization in an Amazonian rainforest supports stoichiometric dissimilarity as a driver of litter diversity effects on decomposition. Proceedings. Biological Sciences, 281(1796), 20141682. https://doi.org/10.1098/rspb.2014.1682

Bardgett, R. D., \& Caruso, T. (2020). Soil microbial community responses to climate extremes: resistance, resilience and transitions to alternative states. Philosophical Transactions of the Royal Society of London. Series B, Biological Sciences, 375(1794), 20190112. https://doi.org/10.1098/rstb.2019.0112 
Bardgett, R. D., Mommer, L., \& De Vries, F. T. (2014). Going underground: Root traits as drivers of ecosystem processes. Trends in Ecology and Evolution, 29(12), 692-699. https://doi.org/10.1016/j.tree.2014.10.006

Bardgett, R. D., \& van der Putten, W. H. (2014). Belowground biodiversity and ecosystem functioning. Nature, 515(7528), 505-511. https://doi.org/10.1038/nature13855

Bartoń, K. (2019). Multi-Model Inference. R package version 1.43 .4 (pp. 13-17). pp. 13-17. Retrieved from http://mumin.r-forge.r-project.org/MuMIn-manual.pdf

Bates, D., Maechler, M., Bolker, B., Walker, S., Chistensen, R. H. B., Singman, H., .. Fox, J. (2019). Linear mixed-effects models using “Eigen” and S4.

Beare, M. H., Neely, C. L., Coleman, D. C., \& Hargrove, W. L. (1990). A substrate-induced respiration (SIR) method for measurement of fungal and bacterial biomass on plant residues. Soil Biology and Biochemistry, 22(5), 585-594. https://doi.org/10.1016/00380717(90)90002-H

Becher, D., Bernhardt, J., Fuchs, S., \& Riedel, K. (2013). Metaproteomics to unravel major microbial players in leaf litter and soil environments: Challenges and perspectives. Proteomics, 13(18-19), 2895-2909. https://doi.org/10.1002/pmic.201300095

Bergmann, J., Weigelt, A., van der Plas, F., Laughlin, D. C., Kuyper, T. W., GuerreroRamirez, N., ... Mommer, L. (2020). The fungal collaboration gradient dominates the root economics space in plants. Science Advances, 6(27), eaba3756. https://doi.org/10.1126/sciadv.aba3756

Burnham, K. P., \& Anderson, D. R. (2002). Model Selection and Multimodel Inference (2nd ed.). New York: Springer-Verlag New York, Inc.

Cesarz, S., Fender, A. C., Beyer, F., Valtanen, K., Pfeiffer, B., Gansert, D., ... Scheu, S. (2013). Roots from beech (Fagus sylvatica L.) and ash (Fraxinus excelsior L.) differentially affect soil microorganisms and carbon dynamics. Soil Biology and 
Biochemistry, 61, 23-32. https://doi.org/10.1016/j.soilbio.2013.02.003

Chen, C., Chen, H. Y. H., Chen, X., \& Huang, Z. (2019). Meta-analysis shows positive effects of plant diversity on microbial biomass and respiration. Nature Communications, 10(1), 1-10. https://doi.org/10.1038/s41467-019-09258-y

Chen, L., Xiang, W., Wu, H., Ouyang, S., Zhou, B., Zeng, Y., ... Kuzyakov, Y. (2019). Tree species identity surpasses richness in affecting soil microbial richness and community composition in subtropical forests. Soil Biology and Biochemistry, 130(May 2018), 113121. https://doi.org/10.1016/j.soilbio.2018.12.008

Cleveland, C. C., \& Liptzin, D. (2007). C:N:P stoichiometry in soil: Is there a "Redfield ratio" for the microbial biomass? Biogeochemistry, 85(3), 235-252. https://doi.org/10.1007/s10533-007-9132-0

Coq, S., Souquet, J.-M., Meudec, E., Cheynier, V., \& Hättenschwiler, S. (2010). Interspecific variation in leaf litter tannins drives decomposition in a tropical rain forest of French Guiana. Ecology, 91(7), 2080-2091. https://doi.org/10.1890/09-1076.1

Cornwell, W. K., Cornelissen, J. H. C., Amatangelo, K., Dorrepaal, E., Eviner, V. T., Godoy, O., ... Westoby, M. (2008). Plant species traits are the predominant control on litter decomposition rates within biomes worldwide. Ecology Letters, 11(10), 1065-1071. https://doi.org/10.1111/j.1461-0248.2008.01219.x

Crowther, T. W., van den Hoogen, J., Wan, J., Mayes, M. A., Keiser, A. D., Mo, L., ... Maynard, D. S. (2019). The global soil community and its influence on biogeochemistry. Science, 365(6455), eaav0550. https://doi.org/10.1126/science.aav0550

Dawud, S. M., Raulund-Rasmussen, K., Domisch, T., Finér, L., Jaroszewicz, B., \& Vesterdal, L. (2016). Is Tree Species Diversity or Species Identity the More Important Driver of Soil Carbon Stocks, C/N Ratio, and pH? Ecosystems, 19(4), 645-660. https://doi.org/10.1007/s10021-016-9958-1 
Dijkstra, F. A., West, J. B., Hobbie, S. E., \& Reich, P. B. (2009). Antagonistic effects of species on $\mathrm{C}$ respiration and net $\mathrm{N}$ mineralization in soils from mixed coniferous plantations. Forest Ecology and Management, 257(3), 1112-1118. https://doi.org/10.1016/j.foreco.2008.11.014

Eisenhauer, N., Beßler, H., Engels, C., Gleixner, G., Habekost, M., Milcu, A., ... Scheu, S. (2010). Plant diversity effects on soil microorganisms support the singular hypothesis. Ecology, 91(2), 485-496. https://doi.org/10.1890/08-2338.1

Eisenhauer, N., Lanoue, A., Strecker, T., Scheu, S., Steinauer, K., Thakur, M. P., \& Mommer, L. (2017). Root biomass and exudates link plant diversity with soil bacterial and fungal biomass. Scientific Reports, 7, 1-8. https://doi.org/10.1038/srep44641

Fanin, N., Hättenschwiler, S., Barantal, S., Schimann, H., \& Fromin, N. (2011). Does variability in litter quality determine soil microbial respiration in an Amazonian rainforest? Soil Biology and Biochemistry, 43(5), 1014-1022. https://doi.org/10.1016/J.SOILBIO.2011.01.018

Fanin, N., Hättenschwiler, S., \& Fromin, N. (2014). Litter fingerprint on microbial biomass, activity, and community structure in the underlying soil. Plant and Soil, 379(1-2), 7991. https://doi.org/10.1007/s11104-014-2051-7

Fierer, N. (2017). Embracing the unknown: disentangling the complexities of the soil microbiome. Nature Reviews Microbiology, 15(10), 579-590. https://doi.org/10.1038/nrmicro.2017.87

Fierer, N., \& Jackson, R. B. (2006). The diversity and biogeography of soil bacterial communities. Proceedings of the National Academy of Sciences of the United States of America, 103(3), 626-631. https://doi.org/10.1073/pnas.0507535103

Forrester, D. I. (2017). Ecological and Physiological Processes in Mixed Versus Monospecific Stands. In H. Pretzsch, D. I. Forrester, \& J. Bauhus (Eds.), Mixed-Species Forests: 
Ecology and Management (pp. 73-115). https://doi.org/10.1007/978-3-662-54553-9_3

727

728

729

730

731

732

733

734

735

736

737

738

739

740

741

742

743

744

Freschet, G. T., Aerts, R., \& Cornelissen, J. H. C. (2012). A plant economics spectrum of litter decomposability. Functional Ecology, 26(1), 56-65. https://doi.org/10.1111/j.13652435.2011.01913.x

Freschet, G. T., Cornwell, W. K., Wardle, D. A., Elumeeva, T. G., Liu, W., Jackson, B. G., ... Cornelissen, J. H. C. (2013). Linking litter decomposition of above- and below-ground organs to plant-soil feedbacks worldwide. Journal of Ecology, 101(4), 943-952. https://doi.org/10.1111/1365-2745.12092

Frey, S. D. (2015). The Spatial Distribution of Soil Biota. In Soil Microbiology Ecology and Biochemistry (4th ed., pp. 223-244). https://doi.org/10.1016/B978-0-12-415955$6.00008-6$

Grace, J. B., Scheiner, S. M., \& Schoolmaster, D. R. J. (2015). Structural equation modeling: building and evaluating causal models. Ecological Statistics: Contemporary Theory and Application, (January), 168-199. https://doi.org/10.1080/10705510802154356

Grimshaw, H. M., Allen, S. E., \& Parkinson, J. A. (1989). Nutrient elements. In Chemical Analysis of Ecological Materials, (2nd ed.) (pp. 81-159). Oxford: Blackwell Scientific Publications.

Guo, D., Xia, M., Wei, X., Chang, W., Liu, Y., \& Wang, Z. (2008). Anatomical traits associated with absorption and mycorrhizal colonization are linked to root branch order in twenty-three Chinese temperate tree species. New Phytologist, 180(3), 673-683. https://doi.org/10.1111/j.1469-8137.2008.02573.x

Guyonnet, J. P., Cantarel, A. A. M., Simon, L., \& Haichar, F. Z. (2018). Root exudation rate as functional trait involved in plant nutrient-use strategy classification. International Journal of Business Innovation and Research, 17(3), 8573-8581. https://doi.org/10.1002/ece3.4383 
Handa, I. T., Aerts, R., Berendse, F., Berg, M. P., Bruder, A., Butenschoen, O., ... Hättenschwiler, S. (2014). Consequences of biodiversity loss for litter decomposition across biomes. Nature, 509(7499), 218-221. https://doi.org/10.1038/nature13247

Hättenschwiler, S., Tiunov, A. V., \& Scheu, S. (2005). Biodiversity and Litter Decomposition in Terrestrial Ecosystems. Annual Review of Ecology, Evolution, and Systematics, 36(1), 191-218. https://doi.org/10.1146/annurev.ecolsys.36.112904.151932

Hatton, P. J., Castanha, C., Torn, M. S., \& Bird, J. A. (2015). Litter type control on soil C and N stabilization dynamics in a temperate forest. Global Change Biology, 21(3), 13581367. https://doi.org/10.1111/gcb.12786

Henneron, L., Cros, C., Picon-Cochard, C., Rahimian, V., \& Fontaine, S. (2019). Plant economic strategies of grassland species control soil carbon dynamics through rhizodeposition. Journal of Ecology, (January), 1-18. https://doi.org/10.1111/13652745.13276

Huston, M. A. (1997). Hidden treatments in ecological experiments: Re-evaluating the ecosystem function of biodiversity. Oecologia, 110(4), 449-460. https://doi.org/10.1007/s004420050180

ISRIC, \& FAO. (2002). Procedures for soil analysis, sixth ed. Wageningen: ISRIC. Jackson, R. B., Mooney, H. A., \& Schulze, E.-D. (1997). A global budget for fine root biomass, surface area, and nutrient contents. Proceedings of the National Academy of Sciences, 94(14), 7362-7366. https://doi.org/10.1073/pnas.94.14.7362

Joly, F.-X., Fromin, N., Kiikkilä, O., \& Hättenschwiler, S. (2016). Diversity of leaf litter leachates from temperate forest trees and its consequences for soil microbial activity. Biogeochemistry, 129(3), 373-388. https://doi.org/10.1007/s10533-016-0239-z

Jones, D. L., Hodge, A., \& Kuzyakov, Y. (2004). Plant and mycorrhizal regulation of rhizodeposition. New Phytologist, 163(3), 459-480. https://doi.org/10.1111/j.1469- 
777

778

779

780

Kara, Ö., Bolat, I., Çakiroğlu, K., \& Öztürk, M. (2008). Plant canopy effects on litter accumulation and soil microbial biomass in two temperate forests. Biology and Fertility of Soils, 45(2), 193-198. https://doi.org/10.1007/s00374-008-0327-x

Kassambara, A., \& Mundt, F. (2019). factoextra : Extract and Visualize the Results of Multivariate Data Analyses. Retrieved from https://cran.rproject.org/web/packages/factoextra/factoextra.pdf

Kaštovská, E., Edwards, K., Picek, T., \& Šantrůčková, H. (2015). A larger investment into exudation by competitive versus conservative plants is connected to more coupled plantmicrobe N cycling. Biogeochemistry, 122(1), 47-59. https://doi.org/10.1007/s10533014-0028-5

Khlifa, R., Paquette, A., Messier, C., Reich, P. B., \& Munson, A. D. (2017). Do temperate tree species diversity and identity influence soil microbial community function and composition? Ecology and Evolution, 7(19), 7965-7974. https://doi.org/10.1002/ece3.3313

Kong, D., Wang, J., Wu, H., Valverde-Barrantes, O. J., Wang, R., Zeng, H., ... Feng, Y. (2019). Nonlinearity of root trait relationships and the root economics spectrum. Nature Communications, 10(1), 2203. https://doi.org/10.1038/s41467-019-10245-6

Kou, L., Jiang, L., Hättenschwiler, S., Zhang, M., Niu, S., Fu, X., ... Wang, H. (2020). Diversity-decomposition relationships in forests worldwide. ELife, 9, 1-51. https://doi.org/10.7554/eLife.55813

Lafleur, B., Paré, D., Munson, A. D., \& Bergeron, Y. (2010). Response of northeastern North American forests to climate change: Will soil conditions constrain tree species migration? Environmental Reviews, 18(NA), 279-289. https://doi.org/10.1139/A10-013 Landi, L., Valori, F., Ascher, J., Renella, G., Falchini, L., \& Nannipieri, P. (2006). Root 
exudate effects on the bacterial communities, $\mathrm{CO} 2$ evolution, nitrogen transformations and ATP content of rhizosphere and bulk soils. Soil Biology and Biochemistry, 38(3), 509-516. https://doi.org/10.1016/j.soilbio.2005.05.021

Lange, M., Eisenhauer, N., Sierra, C. A., Bessler, H., Engels, C., Griffiths, R. I., ... Gleixner, G. (2015). Plant diversity increases soil microbial activity and soil carbon storage. Nature Communications, 6(1), 6707. https://doi.org/10.1038/ncomms7707

Lange, M., Habekost, M., Eisenhauer, N., Roscher, C., Bessler, H., Engels, C., ... Gleixner, G. (2014). Biotic and abiotic properties mediating plant diversity effects on soil microbial communities in an experimental grassland. PLoS ONE, 9(5). https://doi.org/10.1371/journal.pone.0096182

Lefcheck, J., Byrnes, J., \& Grace, J. (2019). Piecewise Structural Equation Modeling. $R$ Package. Retrieved from https://cran.rproject.org/web/packages/piecewiseSEM/piecewiseSEM.pdf

Lladó, S., López-Mondéjar, R., \& Baldrian, P. (2017). Forest Soil Bacteria: Diversity, involvement in ecosystem processes, and response to global change. Microbiology and Molecular Biology Reviews, 81(2), e00063-16. https://doi.org/10.1128/MMBR.00063-16

Lladó, S., López-Mondéjar, R., \& Baldrian, P. (2018). Drivers of microbial community structure in forest soils. Applied Microbiology and Biotechnology, 102(10), 4331-4338. https://doi.org/10.1007/s00253-018-8950-4

Ma, Z., Guo, D., Xu, X., Lu, M., Bardgett, R. D., Eissenstat, D. M., .. Hedin, L. O. (2018). Evolutionary history resolves global organization of root functional traits. Nature, 555(7694), 94-97. https://doi.org/10.1038/nature25783

Makarov, M. I., Mulyukova, O. S., Malysheva, T. I., \& Menyailo, O. V. (2013). Influence of drying of the samples on the transformation of nitrogen and carbon compounds in mountain-meadow alpine soils. Eurasian Soil Science, 46(7), 778-787. 
827

828

829

830

McCormack, M. L., Dickie, I. A., Eissenstat, D. M., Fahey, T. J., Fernandez, C. W., Guo, D., ... Zadworny, M. (2015). Redefining fine roots improves understanding of below-ground contributions to terrestrial biosphere processes. New Phytologist, 207(3), 505-518. https://doi.org/10.1111/nph.13363

McCormack, M. L., \& Iversen, C. M. (2019). Physical and Functional Constraints on Viable Belowground Acquisition Strategies. Frontiers in Plant Science, 10(October), 1-12. https://doi.org/10.3389/fpls.2019.01215

Nakazawa, M. (2019). fmsb: Functions for Medical Statistics Book with some Demographic Data. https://doi.org/https://CRAN.R-project.org/package=fmsb

Oksanen, J., Blanchet, F. G., Friendly, M., Kindt, R., Legendre, P., Mcglinn, D., ... Maintainer, H. W. (2019). Package “vegan” Title Community Ecology Package. Community Ecology Package, 2(9), 1-297. Retrieved from https://cran.rproject.org/web/packages/vegan/vegan.pdf

Paul, E. A. (2007). Soil microbiology, ecology, and biochemistry (3rd ed.). Burlington: Academic Press.

Pfeiffer, B., Fender, A. C., Lasota, S., Hertel, D., Jungkunst, H. F., \& Daniel, R. (2013). Leaf litter is the main driver for changes in bacterial community structures in the rhizosphere of ash and beech. Applied Soil Ecology, 72, 150-160. https://doi.org/10.1016/j.apsoil.2013.06.008

Phillips, N. (2018). Yarrr! The pirate's guide to R. Retrieved from https://bookdown.org/ndphillips/YaRrr/

Pinay, G., Barbera, P., Carreras-Palou, A., Fromin, N., Sonié, L., Madeleine Couteaux, M., ... Lensi, R. (2007). Impact of atmospheric CO2 and plant life forms on soil microbial activities. Soil Biology and Biochemistry, 39(1), 33-42. 
Porter, L. J., Hrstich, L. N., \& Chan, B. G. (1985). The conversion of procyanidins and prodelphinidins to cyanidin and delphinidin. Phytochemistry, 25(1), 223-230. https://doi.org/10.1016/S0031-9422(00)94533-3

Prescott, C. E. (2005). Decomposition and Mineralization of Nutrients from Litter and Humus. Nutrient Acquisition by Plants, 181, 15-41. https://doi.org/10.1007/3-54027675-0_2

Prescott, C. E., \& Grayston, S. J. (2013). Tree species influence on microbial communities in litter and soil: Current knowledge and research needs. Forest Ecology and Management, 309, 19-27. https://doi.org/10.1016/j.foreco.2013.02.034

R Development Core Team. (2008). R: A Language and Environment for Statistical Computing. Retrieved from http://www.r-project.org

Reich, P. B., Oleksyn, J., Modrzynski, J., Mrozinski, P., Hobbie, S. E., Eissenstat, D. M., ... Tjoelker, M. G. (2005). Linking litter calcium, earthworms and soil properties: a common garden test with 14 tree species. Ecology Letters, 8(8), 811-818. https://doi.org/10.1111/j.1461-0248.2005.00779.x

Ribéreau-Gayon, P. (1972). Plant Phenolics. Edinburgh: Oliver \& Boyd.

Robertson, G. P., \& Groffman, P. M. (2007). Nitrogen Transformations. In Soil Microbiology, Ecology and Biochemistry (pp. 341-364). https://doi.org/10.1016/B978-0-08-047514$1.50017-2$

Roumet, C., Birouste, M., Picon-Cochard, C., Ghestem, M., Osman, N., Vrignon-Brenas, S., ... Stokes, A. (2016). Root structure-function relationships in 74 species: Evidence of a root economics spectrum related to carbon economy. New Phytologist, 210(3), 815-826. https://doi.org/10.1111/nph.13828

Santonja, M., Rancon, A., Fromin, N., Baldy, V., Hättenschwiler, S., Fernandez, C., ... 
Mirleau, P. (2017). Plant litter diversity increases microbial abundance, fungal diversity, and carbon and nitrogen cycling in a Mediterranean shrubland. Soil Biology and Biochemistry, 111, 124-134. https://doi.org/10.1016/j.soilbio.2017.04.006

Scheibe, A., Steffens, C., Seven, J., Jacob, A., Hertel, D., Leuschner, C., \& Gleixner, G. (2015). Effects of tree identity dominate over tree diversity on the soil microbial community structure. Soil Biology and Biochemistry, 81, 219-227. https://doi.org/10.1016/j.soilbio.2014.11.020

Shihan, A., Hättenschwiler, S., Milcu, A., Joly, F.-X., Santonja, M., \& Fromin, N. (2017). Changes in soil microbial substrate utilization in response to altered litter diversity and precipitation in a Mediterranean shrubland. Biology and Fertility of Soils, 53(2), 171185. https://doi.org/10.1007/s00374-016-1166-9

Singh, B. K., Bardgett, R. D., Smith, P., \& Reay, D. S. (2010). Microorganisms and climate change: Terrestrial feedbacks and mitigation options. Nature Reviews Microbiology, 8(11), 779-790. https://doi.org/10.1038/nrmicro2439

Smith, M. S., \& Tiedje, J. M. (1979). Phases of denitrification following oxygen depletion in soil. Soil Biology and Biochemistry, 11(3), 261-267. https://doi.org/10.1016/00380717(79)90071-3

Steinauer, K., Chatzinotas, A., \& Eisenhauer, N. (2016). Root exudate cocktails: the link between plant diversity and soil microorganisms? Ecology and Evolution, 6(20), 73877396. https://doi.org/10.1002/ece3.2454

Sun, T., Hobbie, S. E., Berg, B., Zhang, H., Wang, Q., Wang, Z., \& Hättenschwiler, S. (2018). Contrasting dynamics and trait controls in first-order root compared with leaf litter decomposition. Proceedings of the National Academy of Sciences of the United States of America, 115(41), 10392-10397. https://doi.org/10.1073/pnas.1716595115

Thomas, P. A., \& Packham, J. R. (2007). Ecology of woodlands and forests: Description, 

dynamics and diversity. In Ecology of Woodlands and Forests: Description, Dynamics and Diversity. https://doi.org/10.1017/CBO9780511805578

Thoms, C., Gattinger, A., Jacob, M., Thomas, F. M., \& Gleixner, G. (2010). Direct and indirect effects of tree diversity drive soil microbial diversity in temperate deciduous forest. Soil Biology and Biochemistry, 42(9), 1558-1565. https://doi.org/10.1016/j.soilbio.2010.05.030

Tilman, D., Lehman, C. L., \& Thomson, K. T. (1997). Plant diversity and ecosystem productivity: Theoretical considerations. Proceedings of the National Academy of Sciences of the United States of America, 94(5), 1857-1861. https://doi.org/10.1073/pnas.94.5.1857

Urbanová, M., Šnajdr, J., \& Baldrian, P. (2015). Composition of fungal and bacterial communities in forest litter and soil is largely determined by dominant trees. Soil Biology and Biochemistry, 84, 53-64. https://doi.org/10.1016/j.soilbio.2015.02.011

van Breemen, N., Finzi, A. C., \& Canham, C. D. (1997). Canopy tree-soil interactions within temperate forests: effects of soil elemental composition and texture on species distributions. Canadian Journal of Forest Research, 27(7), 1110-1116. https://doi.org/10.1139/x97-061

Van Soest, P. J. (1963). Use of detergents in the analysis of fibrous feeds. II. A rapid method for the determination of fiber and lignin. Journal of the Association of Official Analytical Chemists, 46, 262-269.

Vivanco, L., \& Austin, A. T. (2008). Tree species identity alters forest litter decomposition through long-term plant and soil interactions in Patagonia, Argentina. Journal of Ecology, 96(4), 727-736. https://doi.org/10.1111/j.1365-2745.2008.01393.x

Wambsganss, J., Beyer, F., Freschet, G. T., Scherer-Lorenzen, M., \& Bauhus, J. (2021). Tree species mixing reduces biomass but increases length of absorptive fine roots in European 
forests. Journal of Ecology, (September 2020), 1365-2745.13675. https://doi.org/10.1111/1365-2745.13675

Wang, F., Che, R., Deng, Y., Wu, Y., Tang, L., Xu, Z., ... Cui, X. (2021). Air-drying and long time preservation of soil do not significantly impact microbial community composition and structure. Soil Biology and Biochemistry, 157(September 2020), 108238. https://doi.org/10.1016/j.soilbio.2021.108238

Waterman, P. G., \& Mole, S. (1994). Analysis of Phenolic Plant Metabolites. Oxford: Blackwell Scientific Publications.

Weemstra, M., Mommer, L., Visser, E. J. W., van Ruijven, J., Kuyper, T. W., Mohren, G. M. J., \& Sterck, F. J. (2016). Towards a multidimensional root trait framework: A tree root review. The New Phytologist, 211(4), 1159-1169. https://doi.org/10.1111/nph.14003

Wright, I. J., Reich, P. B., Westoby, M., Ackerly, D. D., Baruch, Z., Bongers, F., ... Villar, R. (2004). The worldwide leaf economics spectrum. Nature, 428(6985), 821-827. https://doi.org/10.1038/nature02403

Wu, Y. T., Gutknecht, J., Nadrowski, K., Geißler, C., Kühn, P., Scholten, T., ... Buscot, F. (2012). Relationships Between Soil Microorganisms, Plant Communities, and Soil Characteristics in Chinese Subtropical Forests. Ecosystems, 15(4), 624-636. https://doi.org/10.1007/s10021-012-9533-3 
944 Table 1. GLM model averaging results: $R^{2}$ marginal $\left(R^{2} m\right)$, and $R^{2}$ conditional $\left(R^{2} c\right)$, estimated

945 slope (Est.), standard error (SE), importance (Imp.), z-value, and p-values for the response

946 variables: microbial biomass ( $\mu \mathrm{g} \mathrm{C}_{\text {microbial }} \mathrm{g}^{-1}$ dry soil), potential denitrification enzyme activity

947 (DEA; $\mu \mathrm{g} \mathrm{N}-\mathrm{N}_{2} \mathrm{O} \mathrm{g}{ }^{-1}$ dry soil $\mathrm{h}^{-1}$ ), sum of the microbial catabolic respiration induced by 15

948 different C-sources (Sum 15; $\mu \mathrm{g} \mathrm{C}-\mathrm{CO}_{2} \mathrm{~g}^{-1}$ dry soil $\mathrm{h}^{-1}$ ), and Shannon metabolic diversity index

$949\left(H^{\prime}\right)$. Blue and red estimate values indicate positive and negative relationships, respectively.

950 Explanatory variables are abbreviated as: 3-species tree mixture stands (Tree mix.), first and

951 second forest floor litter PCA axis (Litter PC1 and Litter PC2), first and second absorptive root

952 PCA axis (Root PC1 and Root PC2), and first and second soil parameters axis (Soil PC1 and

953 Soil PC2). P-values are coded as such: $\mathrm{p}<0.05^{*}, \mathrm{p}<0.01^{* *}, \mathrm{p}<0.001^{* * *}$.

\begin{tabular}{|c|c|c|c|c|c|c|c|c|c|c|c|c|}
\hline & \multicolumn{6}{|c|}{ Microbial Biomass } & \multicolumn{6}{|c|}{ Denitrification } \\
\hline & \multirow{2}{*}{$\begin{array}{l}R^{2} m= \\
\text { Est. }\end{array}$} & \multirow{2}{*}{$\begin{array}{c}0.35 \\
S E\end{array}$} & \multirow{2}{*}{$\begin{array}{l}R^{2} c= \\
\text { Imp. }\end{array}$} & \multirow{2}{*}{$\frac{0.77}{\text { z-value }}$} & \multicolumn{2}{|c|}{$\mathrm{AIC}=566$} & \multicolumn{2}{|c|}{$R^{2} m=0.23$} & \multirow{2}{*}{$\begin{array}{l}\mathbf{R}^{2} \mathbf{c}= \\
\text { Imp. }\end{array}$} & \multirow{2}{*}{$\begin{array}{l}0.79 \\
\text { z-value }\end{array}$} & \multicolumn{2}{|c|}{$\mathrm{AIC}=875.6$} \\
\hline & & & & & p-value & & Est. & SE & & & p-value & \\
\hline Tree mix. & 0.04 & 0.11 & 0.30 & 0.40 & 0.69 & & -0.10 & 0.21 & 0.33 & 0.46 & 0.65 & \\
\hline Litter PC1 & 0.04 & 0.04 & 0.68 & 1.08 & 0.28 & & 0.05 & 0.06 & 0.53 & 0.76 & 0.45 & \\
\hline Litter PC2 & 0.05 & 0.05 & 0.65 & 1.01 & 0.31 & & 0.22 & 0.07 & 1.00 & 3.00 & 0.003 & $* *$ \\
\hline Root PC1 & -0.01 & 0.02 & 0.27 & 0.35 & 0.73 & & 0.02 & 0.04 & 0.34 & 0.46 & 0.65 & \\
\hline Root PC2 & -0.11 & 0.04 & 1.00 & 2.96 & 0.003 & $* *$ & -0.02 & 0.05 & 0.35 & 0.47 & 0.64 & \\
\hline Soil PC1 & 0.37 & 0.07 & 1.00 & 5.04 & $5.00 \mathrm{E}-07$ & $* * *$ & 0.60 & 0.14 & 1.00 & 4.24 & 0.00002 & $* * *$ \\
\hline \multirow[t]{4}{*}{ Soil PC2 } & 0.00 & 0.04 & 0.20 & 0.05 & 0.96 & & -0.02 & 0.08 & 0.24 & 0.23 & 0.82 & \\
\hline & \multicolumn{6}{|c|}{ Sum15 } & \multicolumn{6}{|c|}{$H^{\prime}$} \\
\hline & \multicolumn{2}{|c|}{$R^{2} m=0.30$} & \multicolumn{2}{|c|}{$R^{2} c=0.67$} & \multirow{2}{*}{\multicolumn{2}{|c|}{$\begin{array}{l}\mathrm{AIC}=396.4 \\
\text {-value }\end{array}$}} & \multicolumn{2}{|c|}{$R^{2} m=0.14$} & \multicolumn{2}{|c|}{$R^{2} c=0.35$} & \multirow{2}{*}{\multicolumn{2}{|c|}{$\begin{array}{l}\text { AIC }=-1905.7 \\
\text { p-value }\end{array}$}} \\
\hline & Est. & SE & Imp. & z-value & & & Est. & SE & Imp. & z-value & & \\
\hline Tree mix. & 0.04 & 0.08 & 0.37 & 0.51 & 0.61 & & -0.0004 & 0.001 & 0.61 & 0.37 & 0.71 & \\
\hline Litter PC1 & 0.00 & 0.01 & 0.26 & 0.27 & 0.79 & & -0.0003 & 0.0004 & 0.30 & 0.70 & 0.48 & \\
\hline Litter PC2 & 0.01 & 0.02 & 0.38 & 0.54 & 0.59 & & 0.00004 & 0.0003 & 0.48 & 0.15 & 0.88 & \\
\hline Root PC1 & -0.02 & 0.03 & 0.60 & 0.91 & 0.36 & & 0.0005 & 0.0005 & 0.22 & 0.96 & 0.34 & \\
\hline Root PC2 & -0.08 & 0.03 & 0.97 & 2.42 & 0.0154 & $*$ & -0.001 & 0.001 & 0.62 & 1.56 & 0.12 & \\
\hline Soil PC1 & 0.23 & 0.04 & 1.00 & 5.22 & $2.00 \mathrm{E}-07$ & $* * *$ & -0.002 & 0.001 & 0.84 & 3.78 & 0.0002 & *** \\
\hline Soil PC2 & 0.00 & 0.02 & 0.22 & 0.07 & 0.94 & & 0.001 & 0.001 & 1.00 & 0.92 & 0.36 & \\
\hline
\end{tabular}


955 Table 2. ANOSIM results for the respiration rates of the 'used' $\mathrm{C}$ sources (defined as at least $95615 \%$ higher than the respiration rates measured with pure water addition). Explanatory variables 957 are abbreviated as: 3-species tree mixture stands (Tree mixture), first and second forest floor 958 litter PCA axes (Litter PC1 and Litter PC2), first and second absorptive root PCA axes (Litter 959 PC1 and Litter PC2), and first and second soil parameters axes (Soil PC1 and Soil PC2). P960 values are coded as such: $\mathrm{p}<0.05^{*}, \mathrm{p}<0.01^{* *}, \mathrm{p}<0.001^{* * *}$.

\begin{tabular}{lccccccc}
\hline & Df & Sums of sqs & Mean sqs & F model & $\mathrm{R}^{2}$ & $\operatorname{Pr}(>\mathrm{F})$ & \\
\hline Tree mixture & 1 & 0.25 & 0.25 & 2.28 & 0.03 & 0.098 &. \\
Litter PC1 & 1 & 0.03 & 0.03 & 0.26 & $3.49 \mathrm{E}-03$ & 0.96 & \\
Litter PC2 & 1 & 0.17 & 0.17 & 1.50 & 0.02 & 0.67 & \\
Root PC1 & 1 & 0.15 & 0.15 & 1.35 & 0.02 & 0.69 & \\
Root PC2 & 1 & 0.39 & 0.39 & 3.54 & 0.05 & 0.04 & $*$ \\
Soil PC1 & 1 & 0.61 & 0.61 & 5.51 & 0.07 & 0.01 & $*$ \\
Soil PC2 & 1 & 0.64 & 0.64 & 5.80 & 0.08 & $1.60 \mathrm{E}-03$ & $* *$ \\
Residuals & 55 & 6.07 & 0.11 & & 0.73 & & \\
Total & 62 & 8.30 & & & 1.00 & & \\
\hline
\end{tabular}



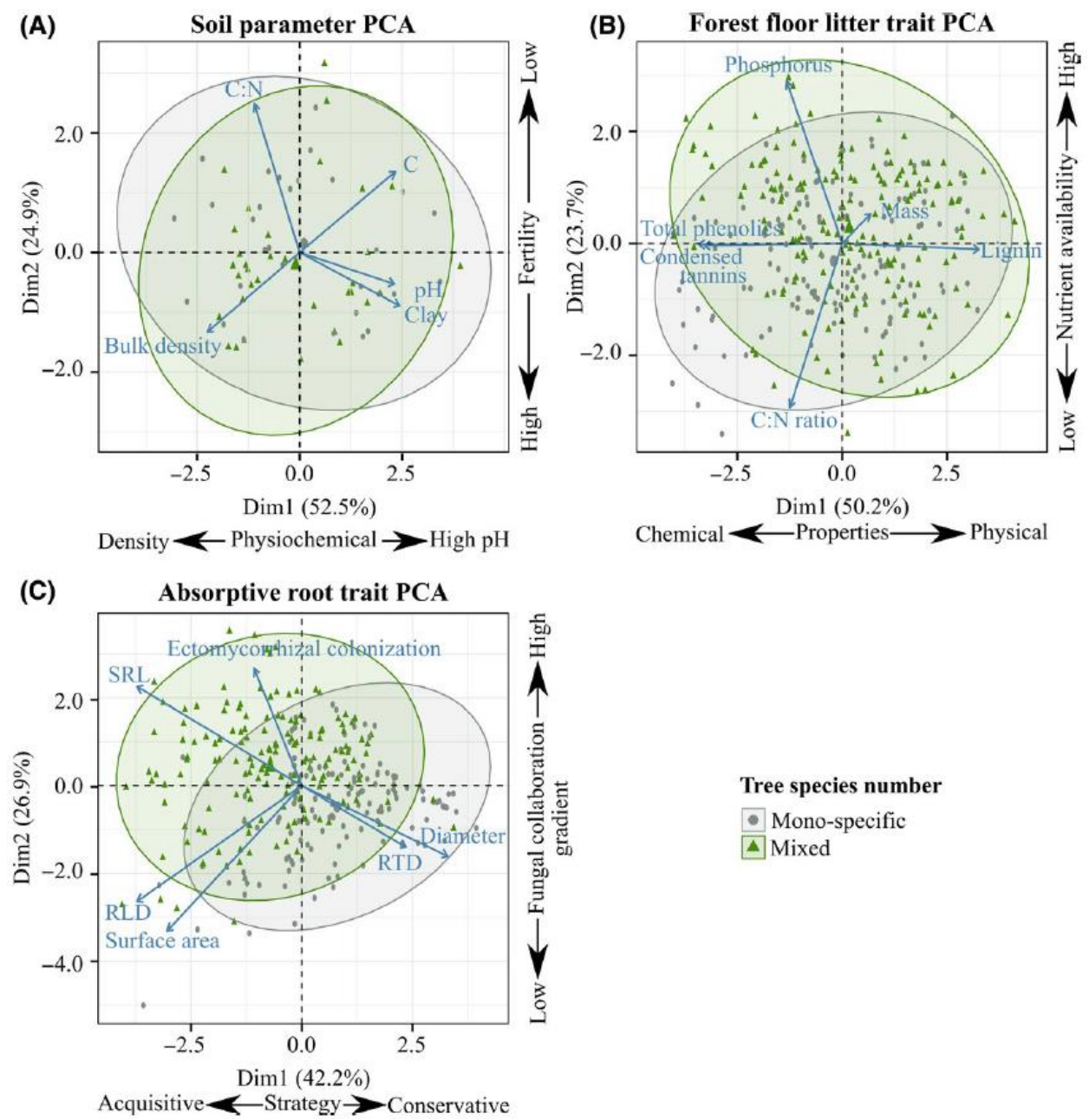

Figure 1. Principal component analyses (PCA) ordination of a. soil parameters, $\mathbf{b}$. forest floor

characteristics, and c. absorptive root traits. Soil parameters (for the first $10 \mathrm{~cm}$ of the A horizon): $\mathrm{BD}=$ bulk density $\left(\mathrm{g} \mathrm{cm}^{-3}\right), \mathrm{C}=$ carbon content $\left(\mathrm{mg} \mathrm{g}^{-1}\right.$ soil $)$, Clay= clay content $(\%)$, $\mathrm{C}: \mathrm{N}=$ carbon to nitrogen ratio, $\mathrm{pH}=$ soil $\mathrm{pH}$. Forest floor characteristics: $\mathrm{C}: \mathrm{N}$ ratio $=$ carbon to nitrogen ratio, Lignin $=$ lignin concentration $\left(\mathrm{g} \mathrm{kg}^{-1}\right.$ dry litter $)$, Mass $=$ litter mass $\left(\mathrm{kg} \mathrm{m}^{-2}\right)$, Phosphorous $=$ phosphorous concentration $(\%)$, Total phenolics $=$ total phenolic concentration $\left(\mathrm{mg} \mathrm{g}^{-1}\right.$ dry litter$)$, Condensed tannins $=$ condensed tannin concentration $(\%)$. Absorptive root

971 traits: Diameter $=$ root diameter $(\mathrm{mm})$, Ectomycorrhizal colonization $=$ ectomycorrhizal 972 colonization intensity $\left(\right.$ number $\left.\mathrm{cm}^{-1}\right), \mathrm{RLD}=$ root length density $\left(\mathrm{cm} \mathrm{cm}^{-3}\right), \mathrm{RTD}=$ root tissue

973 density $\left(\mathrm{g} \mathrm{cm}^{-3}\right), \mathrm{SRL}=$ specific root length $\left(\mathrm{m} \mathrm{g}^{-1}\right)$, Surface area $=$ root surface area $\left(\mathrm{cm}^{2}\right)$.

974 Triangles and circles indicate tree triplets. PCA loadings can be found in Table S4. 


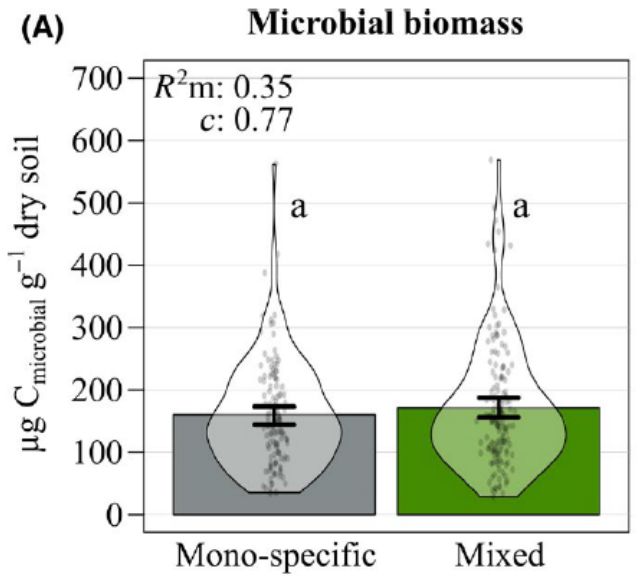

(B) DEA

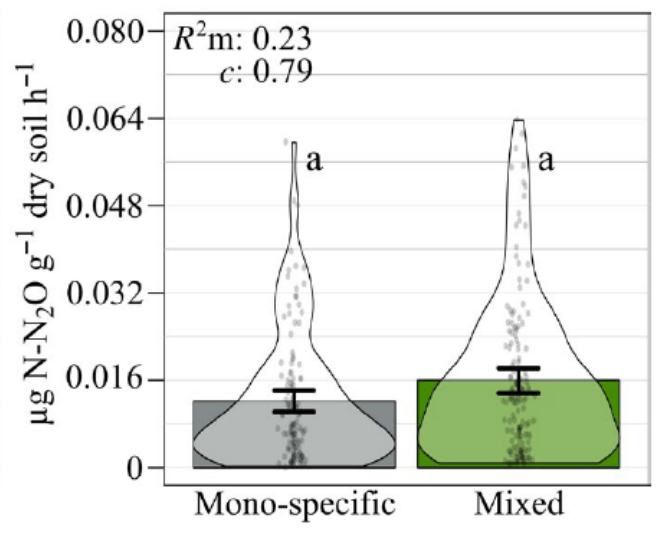

(C)

Sum15

(D) $H^{\prime}$
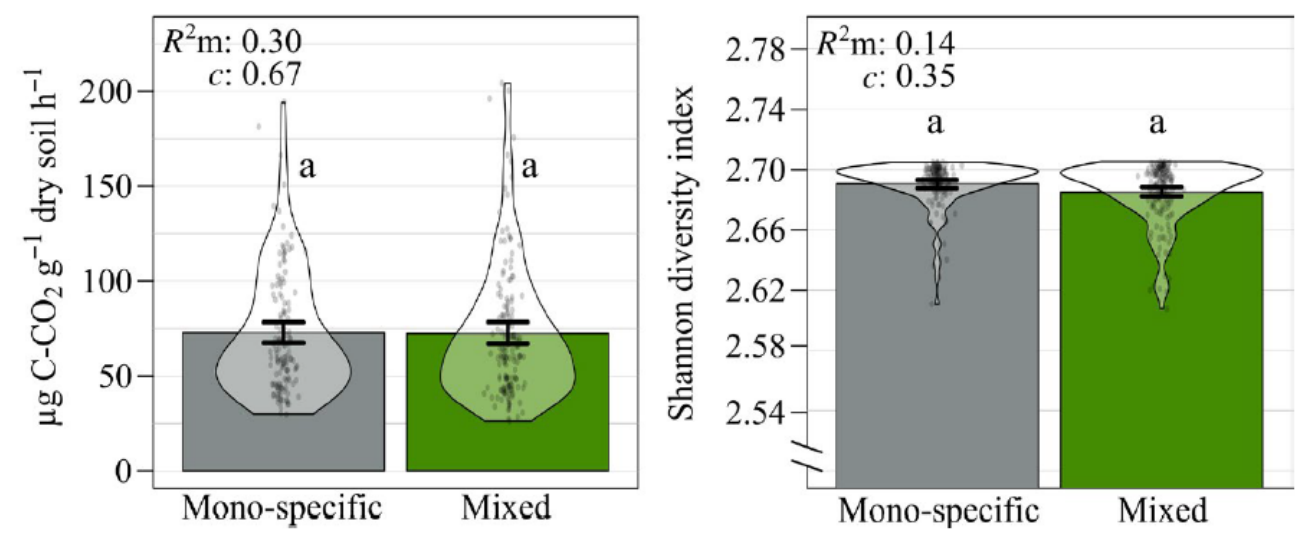

Figure 2. Variations between soil from mono-specific tree stands (gray) or mixed tree stands

977 (green) for microbial biomass $\left(\mu \mathrm{g} \mathrm{C} \mathrm{mic}_{\text {mic }} \mathrm{g}^{-1}\right.$ dry soil), denitrification potential (DEA; $\mu \mathrm{g} \mathrm{N}-\mathrm{N}_{2} \mathrm{O}$

$978 \mathrm{~g}^{-1}$ dry soil $\mathrm{h}^{-1}$ ), sum of the microbial catabolic respiration induced by 15 different $\mathrm{C}$-substrates

979 (Sum 15; $\mu \mathrm{g} \mathrm{C}-\mathrm{CO}_{2} \mathrm{~g}^{-1}$ dry soil $\mathrm{h}^{-1}$ ), and Shannon metabolic diversity index $\left(H^{\prime}\right)$. Marginal $\mathrm{R}^{2}$

$980\left(\mathrm{R}^{2} \mathrm{~m}\right)$ and conditional $\left(\mathrm{R}^{2} \mathrm{c}\right)$ values are from GLM results. There were no statistically significant

981 differences between mono-specific and mixed stand plots (indicated by the same letter "a").

982 Data presented by site and by forest stand type can be found in Figure S4. 


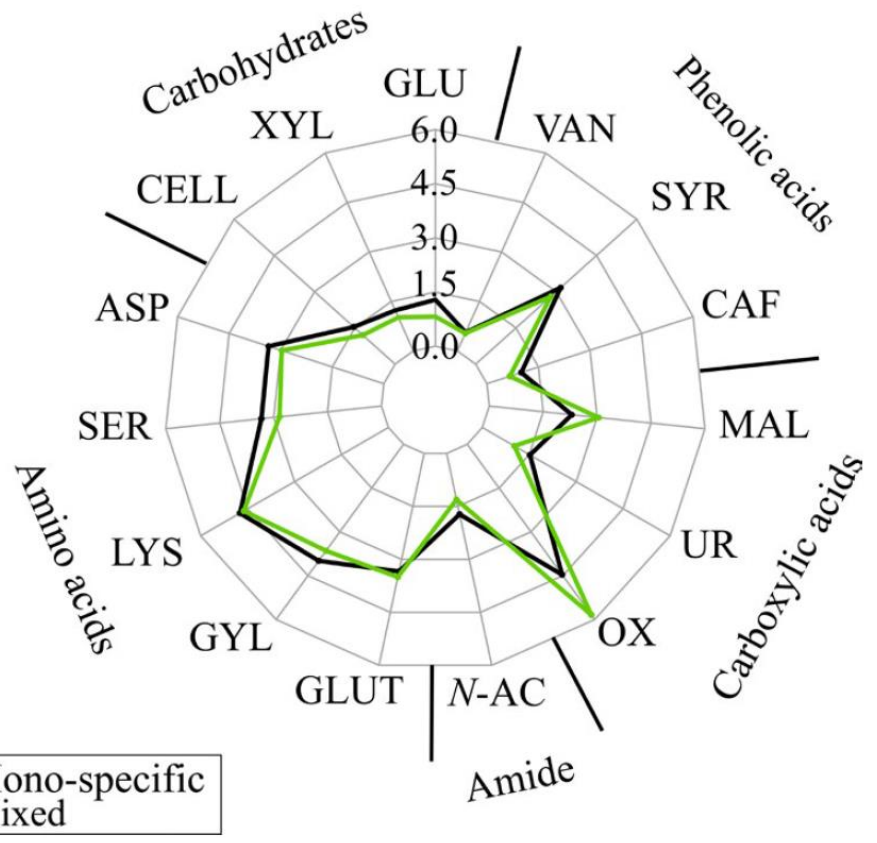

984 Figure 3. Average 'used' $\mathrm{C}$ substrate respiration rates $\left(\mu \mathrm{g} \mathrm{C}-\mathrm{CO}_{2} \mathrm{~g}^{-1}\right.$ dry soil $\mathrm{h}^{-1}$; defined as at 985 least $15 \%$ higher than the respiration rates measured with pure water addition) of the fifteen 986 substrates belonging to five substrate groups for soil from mono-specific tree stands (black) or 987 mixed tree stands (green). Abbreviations: D-glucose (GLU), xylan (XYL), cellulose (CELL), 988 L-asparagine (ASP), L-serine (SER), L-lysine (LYS), L-glycine (GLY), L-glutamine (GLUT), $989 \mathrm{~N}$-acetylglucosamine (N-AC), oxalic acid (OX), uric acid (UR), malic acid (MAL), caffeic acid 990 (CAF), syringic acid (SYR), and vanillic acid (VAN). ANOSIM results showed a marginally 991 significant difference in substrate utilization pattern between mono-specific and mixed stands 992 (Table 2). Data presented by site and by forest stand type can be found in Figure S5. 


\section{(A) Microbial biomass:}

PC1

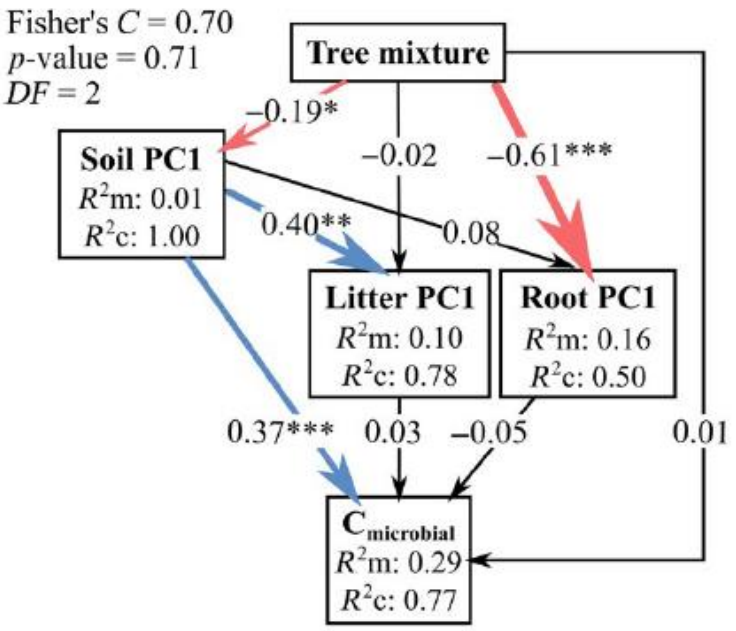

PC2

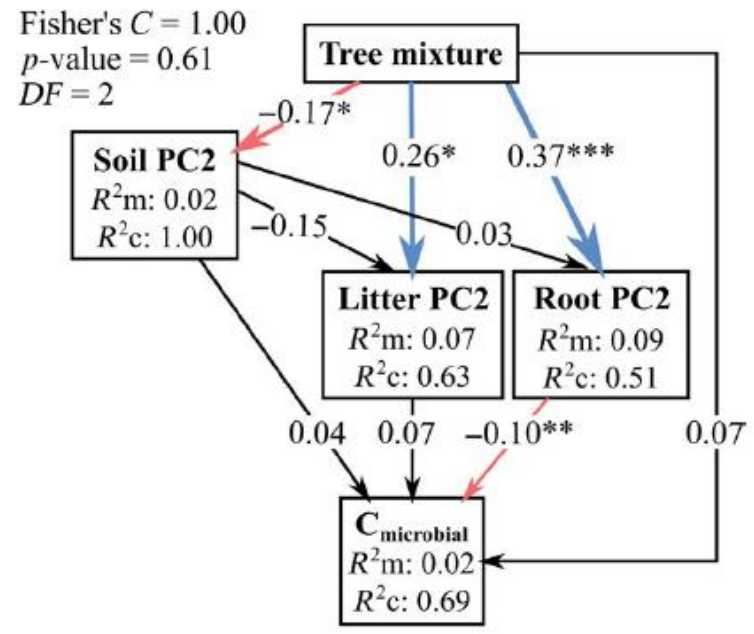

(B) DEA:
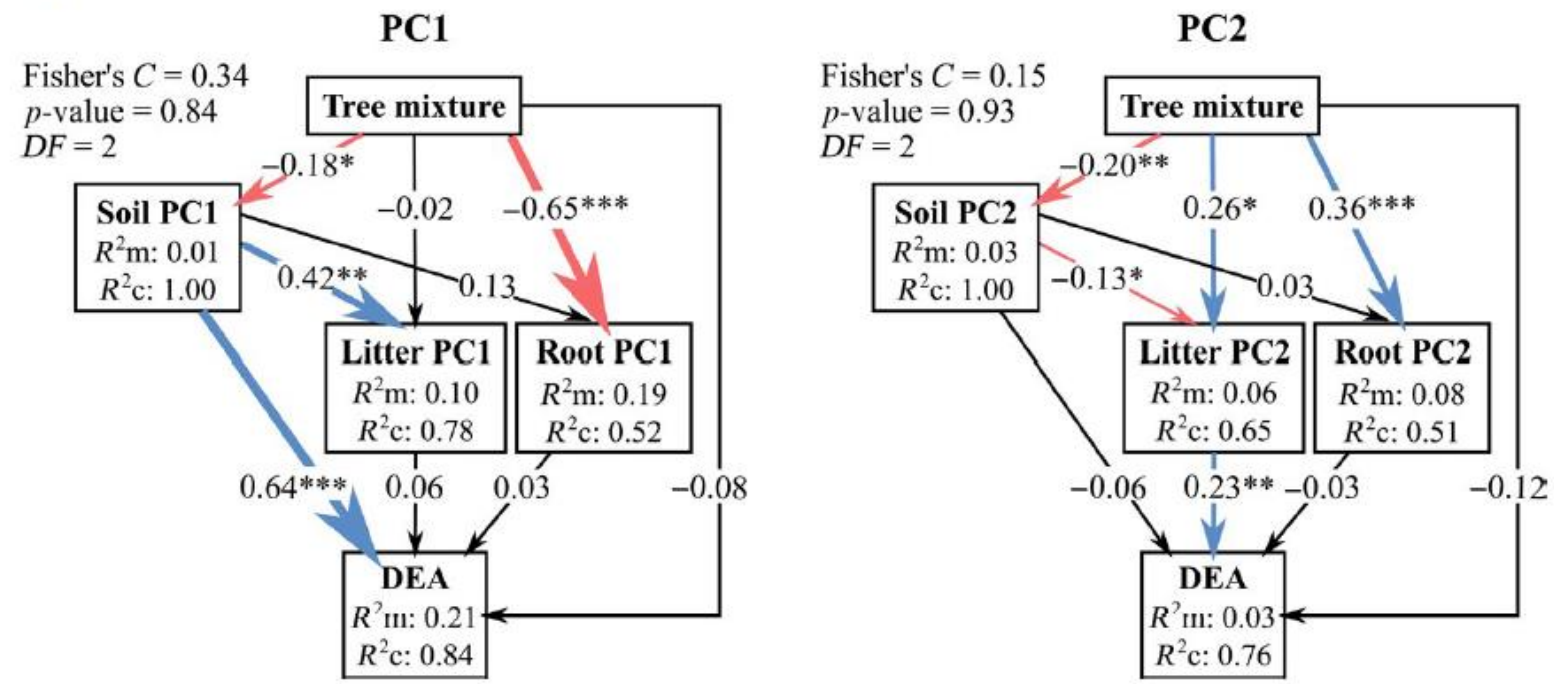

994

Figure 4. Structural equation models (SEM) quantifying the relative importance of the

995 directional causal relationships between 3-species tree mixtures (Tree mixture), forest floor

996 litter characteristics (Litter PC1 and PC2), absorptive root traits (Root PC1 and PC2), and soil

parameters (Soil PC1 and PC2) on soil microbial functioning: a. microbial biomass $\left(\mathrm{C}_{\text {microbial}}\right.$;

$\mu \mathrm{g} \mathrm{C}_{\text {microbial }} \mathrm{g}^{-1}$ dry soil) and b. potential denitrification enzyme activity (DEA; $\mu \mathrm{g} \mathrm{N}-\mathrm{N}_{2} \mathrm{O} \mathrm{g}{ }^{-1}$ arrows, and non-significant relationships by black arrows. Estimate values are positioned on the corresponding arrow, and p-values are coded as such: $\mathrm{p}<0.05^{*}, \mathrm{p}<0.01^{* *}, \mathrm{p}<0.001^{* * *}$. 


\section{(C) Sum15:}

PC1

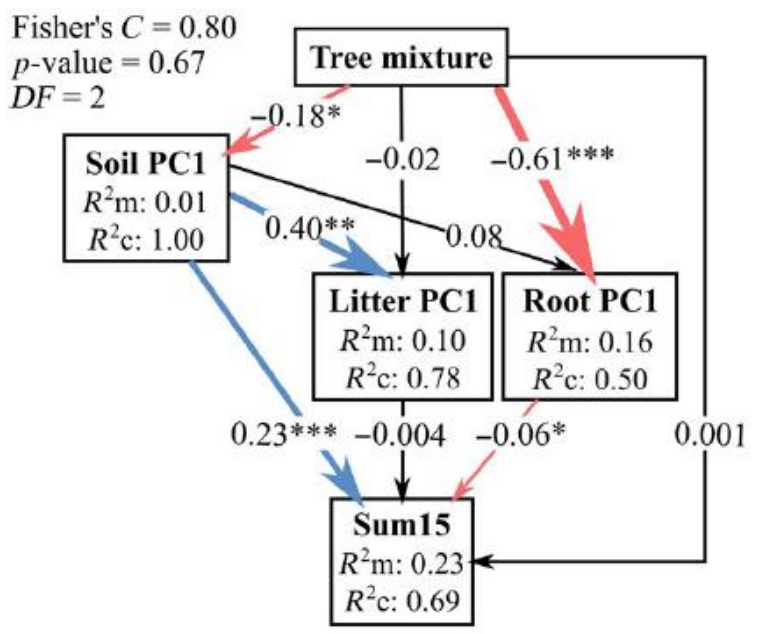

(D) Shannon diversity:

PC1

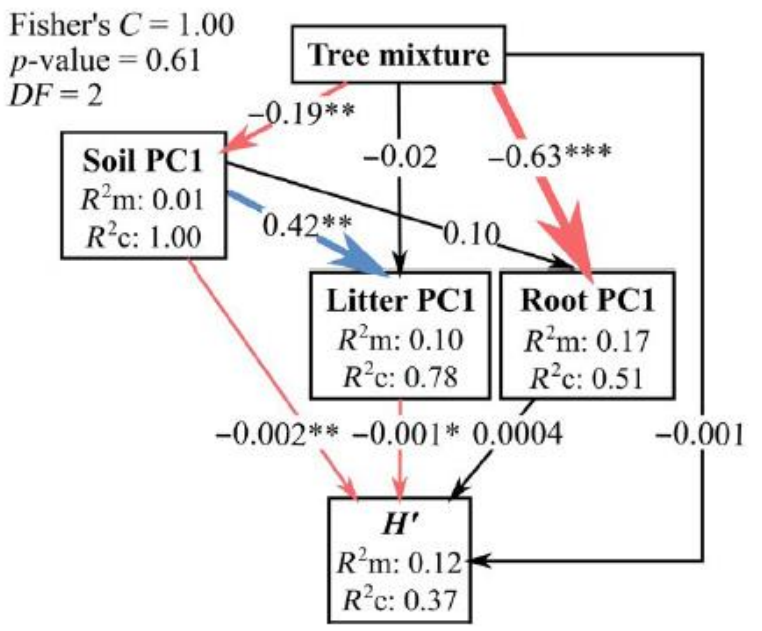

PC2

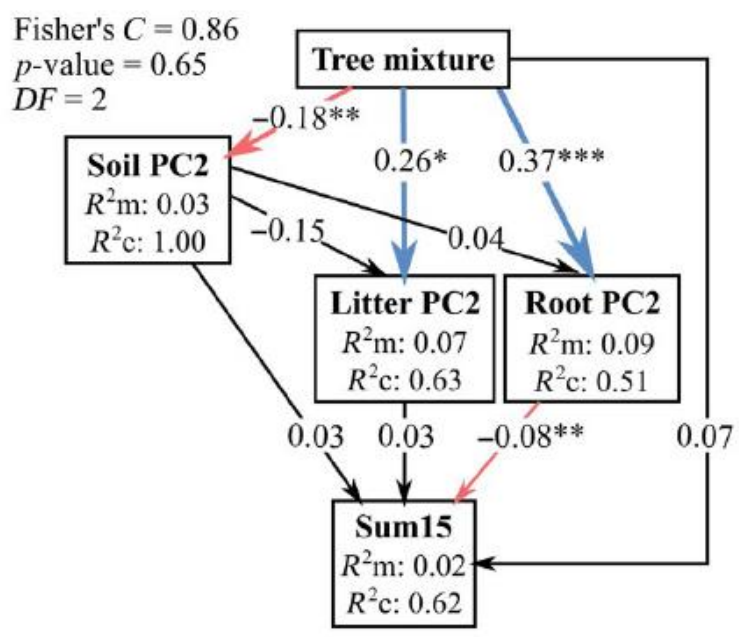

PC2

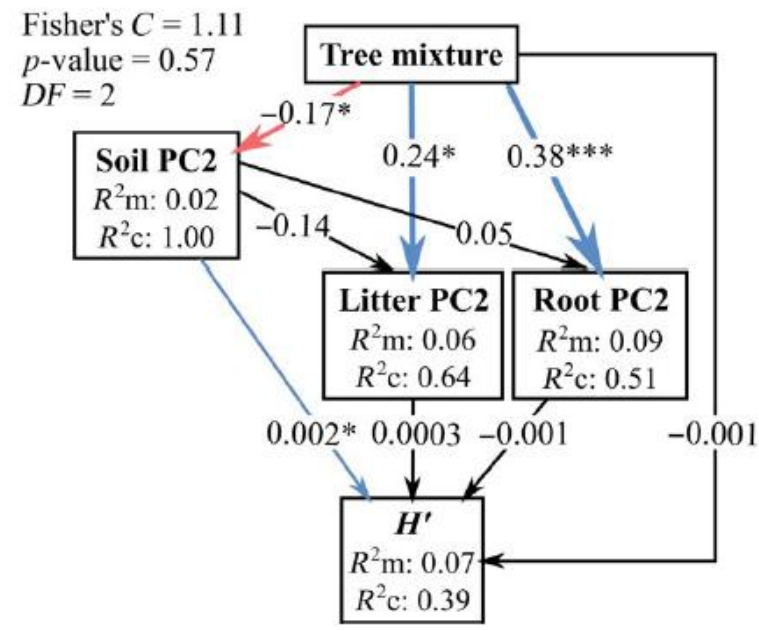

Figure 4 Continued. Structural equation models (SEM) quantifying the relative importance of the directional causal relationships between 3-species tree mixtures (Tree mixture), forest floor litter characteristics (Litter PC1 and PC2), absorptive root traits (Root PC1 and PC2), and soil parameters (Soil PC1 and PC2) on soil microbial functioning: c. sum of the microbial catabolic 1007 respiration induced by 15 different C-sources (Sum $15, \mu \mathrm{g} \mathrm{C}-\mathrm{CO}_{2} \mathrm{~g}^{-1}$ dry soil $\mathrm{h}^{-1}$ ) and d. 1008 Shannon metabolic diversity index $\left(H^{\prime}\right)$. 
1009 Supporting information:

1010 Additional supporting information may be found in the online version of this article.

1011 Figure S1 Field sampling locations.

1012 Table S1 Sampling site information

1013 Table S2 Soil, forest floor litter, and absorptive root analysis results

1014 Table S3 Method and pretreatment used for NIRS calibration

1015 Figure S2 SEM model structure

1016 Table S4 Litter, Root, and Soil PCA Loadings

1017 Table S5 'Used’ C SIR GLMM results

1018 Figure S3 PCA country and stand type variance

1019 Figure S4 Microbial variable country and stand type variance

1020 Figure S5 'Used' C country and stand type variance 